\title{
Deficit irrigation in table grape: eco-physiological basis and potential use to save water and improve quality
}

\author{
M. Permanhani $\cdot$ J. Miguel Costa $\cdot$ M. A. F. Conceição $\cdot$ \\ R. T. de Souza $\cdot$ M. A. S. Vasconcellos $\cdot$ M. M. Chaves
}

Received: 16 December 2015/Accepted: 1 March 2016/Published online: 14 March 2016

(C) Brazilian Society of Plant Physiology 2016

\begin{abstract}
Table grapes are one of the most productive and economically relevant fruit crops worldwide. Table grape production characterizes by high water productivity but also by an intensive use of water, which puts pressure on local/regional water resources, particularly in dry regions (e.g. South Mediterranean, Northeast and Southeast of Brazil). Climate change and scarcer water resources make the problem more severe in those areas. Meanwhile, consumer's demand for quality and sustainable production is increasing and environmental issues are becoming critical for competiveness. In this context, table grape "industry" needs solutions to promote water savings, sustain yield, quality and profit. Deficit irrigation emerged as a tool to mitigate the negative impact of drought on
\end{abstract}

M. Permanhani and J. Miguel Costa contributed equally to this study.

M. Permanhani · J. M. Costa $(\bowtie) \cdot$ M. M. Chaves

LEM-ITQB, Universidade Nova de Lisboa, Av. da

República, EAN, 2780-901 Oeiras, Portugal

e-mail: miguelc@itqb.unl.pt

M. Permanhani

e-mail: permanhaniagro@gmail.com

M. M. Chaves

e-mail: mchaves@itqb.unl.pt

M. Permanhani · M. A. S. Vasconcellos

Fitotecnia, Universidade Federal Rural do Rio de Janeiro,

Seropédica, Rio de Janeiro, Brazil

e-mail: marco.vasconcellos@gmail.com yield and quality and to save water in modern irrigated viticulture. Our aim is to describe the potential benefits of deficit irrigation in table grape production namely in what concerns water savings and berry quality. Previous literature shows that the effect of deficit irrigation on water savings varies with the genotype (scion and rootstock), the environmental conditions as well as the adopted agronomic strategies. This paper provides a comprehensive and up-to-date overview on the eco-physiological basis of deficit irrigation strategies and their role on growth, yield and berry quality (biophysical and biochemical) in table grape. Complementary crop management strategies to guarantee a more sustainable use of water (e.g. higher water use efficiency), improved berry quality and smaller environmental impact of table grape production are presented and discussed.

\author{
J. M. Costa - M. M. Chaves \\ LEAF, Instituto Superior de Agronomia, Universidade de \\ Lisboa, Tapada da Ajuda, 1349-017 Lisboa, Portugal \\ M. A. F. Conceição · R. T. de Souza \\ EMBRAPA Uva e Vinho - EVT Jales, \\ São Paulo 15700-971, Brazil \\ e-mail: marco.conceicao@embrapa.br \\ R. T. de Souza \\ e-mail: reginaldo.souza@embrapa.br
}


Keywords Drought and heat stress - Water use . Stress eco-physiology $\cdot$ Berry yield and quality · Sustainable production

\section{Introduction}

\subsection{Table grape global production}

Grapevine (Vitis vinifera L.) is an important worldwidegrown perennial fruit crop. The species is historically associated with dry and warm Mediterranean climates but both wine and table grape productions are now spread around the globe. We may find nowadays vineyards in subtropical climates or near the equator (e.g. in northeast of Brazil) where two harvests are done per year (Camargo et al. 2012; Jones et al. 2012; Seccia et al. 2015).

Table grape production represents less than $20 \%$ of global grapevine cultivated area (Table 1). In 2014, world's production was estimated in about 21 million tons (Mt) (Seccia et al. 2015). China is the world's leader with an annual value of about $8 \mathrm{Mt}$, while India and Brazil are among the largest producers in tropical regions (Jogaiah et al. 2013; Demir 2014). Brazil is the third largest table grape producer in America, with a cultivated area of about 24,900 ha and an output of about $0.76 \mathrm{Mt}$ (Table 1). Meanwhile, in some countries the area has stabilized or even decreased such as in Portugal, Spain, Italy, Chile, or USA (California) (Nóbrega 2013; Martínez Barba 2015; INTRACEN 2015), which can be attributed to higher production costs, increased competition with other supply countries, resources limitation (e.g. severe water scarcity, such as the case of California) and to technological developments that facilitate and make more profitable transportation and international transactions (USDA-FAS 2014a, 2015a; Seccia et al. 2015).

\subsection{Water use in table grape production: irrigation needs, risks and trends}

Water shortage is the most significant limiting factor of crop production worldwide (Costa et al. 2007; Cominelli et al. 2009; FAO 2011; Mancosu et al. 2015). The situation becomes more problematic in areas characterized by Temperate, Tropical (arid and semi arid) or Mediterranean type climates, namely the northeast of Brazil, the central and southern India, the southern Mediterranean Europe, Turkey or the western part of Australia (Satisha et al. 2006; Teixeira et al. 2014; García-Tejero et al. 2014). Therefore, in these regions table grape is usually grown under irrigated conditions (Satisha et al. 2006; Williams et al. 2010; Camargo et al. 2012; Tarricone et al. 2012).

Crop irrigation optimizes yield and guarantees quality in dry areas. However, it has also become a major user of water resources worldwide representing an average of 70-80\% of total water consumption in arid or semi-arid countries (Fereres and Soriano 2007; FAO 2011). The tendency is for an increase due to the predicted higher air temperatures $\left(\mathrm{T}_{\text {air }}\right)$, higher air evaporative demand and decreased precipitation as result of the ongoing climate change (Costa et al. 2007, 2016; Morison et al. 2008; Elliott et al. 2014; VicenteSerrano et al. 2014).

Compared to wine grapes and other crops, table grapes characterize by very high annual yields (17.1 and 49.9 ton $\mathrm{ha}^{-1}$ ) and a considerably high water productivity (yield/profit vs water use) (Teixeira et al. 2009; Molden et al. 2010; Pereira et al. 2012). However, such high yields are paralleled by very high water inputs as means to minimize risks of yield loss or low berry quality (Rodríguez et al. 2010; ZúñigaEspinoza et al. 2015).

In some important table grape producing regions in Europe and America, the amount of irrigation water used largely overrides precipitation recharge (Table 2). However, seasonal water requirements and vineyard water use vary considerably. The average values of crop evapotranspiration $\left(\mathrm{ET}_{\mathrm{c}}\right)$ can range between 2.2 to $5.6 \mathrm{~mm} \mathrm{day}^{-1}$ (Table 2). This variation mainly derives from differences in environmental conditions (e.g. evaporative demand, soil type) and crop characteristics (e.g. genotype, canopy architecture) or agronomic strategies (e.g. trellis system, use of covering plastic/ netting, weed control, planting density) in the different regions, which will influence ground cover fraction, and consequently, soil water loss (Netzer et al. 2005; Proffitt and Clause 2011; Moratiel and Martínez-Cob 2012; Conceição et al. 2012; Suvočarev et al. 2013).

\subsection{Drought and heat stress: short and long term solutions}

Scarcer water resources, high $\mathrm{T}_{\text {air }}$ and evaporative demand co-occur in most of the producing areas of table grape (Table 2). Besides, climate change is 
Table 1 Non exhaustive list of the main producers of table grapes worldwide in 2014

\begin{tabular}{|c|c|c|c|c|c|}
\hline $\begin{array}{l}\text { Continent and } \\
\text { countries }\end{array}$ & $\begin{array}{l}\text { Total area } \\
\text { grapevine } \\
(\times 1000 \mathrm{ha})\end{array}$ & $\begin{array}{l}\text { Table grape area } \\
(\times 1000 \text { ha })\end{array}$ & $\begin{array}{l}\% \text { Table grape } \\
\text { area/total }\end{array}$ & $\begin{array}{l}\text { Production } \\
\text { Table grape } \\
(\times 1000 \text { ton })\end{array}$ & Source \\
\hline \multicolumn{6}{|l|}{ Asia } \\
\hline China & 799 & 735 & 92.0 & 9000 & OIV (2015), USDA-FAS (2014c) \\
\hline India & 120.2 & - & - & 2195 & Wine Institute (2014), OIV (2015) \\
\hline Iran & 223 & - & - & 1356 & OIV (2015) \\
\hline Turkey & 502 & 295 & 58.8 & 1920 & OIV (2015), USDA-FAS (2014d) \\
\hline \multicolumn{6}{|l|}{ America } \\
\hline USA & 425 & 44.5 & 10.5 & 920 & OIV (2015), USDA-FAS $(2015 a, b)$ \\
\hline Chile & 211 & 52.2 & 24.7 & 1205 & OIV (2015), USDA-FAS (2015c) \\
\hline Brazil & 81 & 24.9 & 30.5 & 762 & CEPEA (2015), de Mello (2015) \\
\hline Peru & - & 27 & - & 540 & USDA-FAS (2014e, 2015a) \\
\hline Argentina & 228 & 12.9 & 5.7 & 130 & INV (2014), USDA-FAS (2015a) \\
\hline \multicolumn{6}{|l|}{ Europe } \\
\hline Italy & 690 & 53.9 & 7.8 & 960 & OIV (2015), USDA-FAS $(2014 a, b)$ \\
\hline Spain & 1038 & 13.5 & 1.3 & 229 & OIV (2015), MAGRAMA (2015) \\
\hline Greece & 110 & 17 & 15.5 & 298 & OIV (2015), USDA-FAS (2014a) \\
\hline France & 792 & 4.9 & 0.6 & 44 & OIV (2015), EU (2015) \\
\hline Portugal & 224 & 2.1 & 0.9 & 14.4 & OIV (2015), INE (2014) \\
\hline \multicolumn{6}{|l|}{ Africa } \\
\hline Egypt & - & 68.9 & - & 1360 & FRUITLINKCO (2015) \\
\hline South Africa & 132 & 16.4 & 12.4 & 340 & OIV (2015), USDA-FAS (2015d) \\
\hline \multicolumn{6}{|l|}{ Oceania } \\
\hline Australia & 154 & 8 & 5.2 & 120 & OIV (2015), ATGA (2015) \\
\hline World total & 7573 & 1389 & 18.3 & 21,553 & OIV (2015), USDA-FAS (2015a) \\
\hline
\end{tabular}

expected to decrease precipitation and result in higher average and maximum $\mathrm{T}_{\text {air }}$ values and in more extreme climate events (e.g. heat waves, severe droughts), which tends to be more frequent and longer as predicted for the Mediterranean basin region (Della-Marta et al. 2007; Jones et al. 2012; IPCC 2013; Fraga et al. 2015). However, other grapevine growing regions (e.g. USA, Australia, northeast of Brazil) are also experiencing the consequences of climate change (Jones et al. 2012; IPCC 2013). In the case of table grapes, severe drought and high $\mathrm{T}_{\text {air }}$ during ripening (i.e. at 27 or $30{ }^{\circ} \mathrm{C}$ ) are known to prevent proper berry color development in colored table grape cultivars (Peppi et al. 2006; Ferrara et al. 2015; Shinomiya et al. 2015; Conesa et al. 2016).

Short and long term solutions to mitigate climate change effects and related stresses (heat, drought), save water and minimize environmental burdens of table grape production are partly similar to what has been described for wine grapes (Gerling 2015; Medrano et al. 2015; Costa et al. 2016). They will include for example: (1) improved crop monitoring and more precise irrigation (precise scheduling, deficit irrigation); (2) improved selection and breeding (optimal scion/rootstock combinations for improved stress resistance and higher WUE); (3) use of soil mulching; (4) use of protected cultivation (netting or plastic covering) (Fig. 1); (5) ensure the proper operation and maintenance of the irrigation system; (6) implement water metrics and water use benchmarking.

\section{Deficit irrigation strategies in table grape}

Attending to the large water requirements of the crop (2700-9500 $\mathrm{m}^{3} \mathrm{ha}^{-1}$ per season) (Table 2) and considering the scarce water resources of most of the producing regions, table grape growers and related 
Table 2 Climate conditions and irrigation water requirements for different table grape cultivars grown in indicative locations in Europe (Portugal, Italy, Spain) and in America (Chile, USA, Brazil)

\begin{tabular}{|c|c|c|c|c|c|c|c|}
\hline \multirow{2}{*}{$\begin{array}{l}\text { Location } \\
\text { (climate type) }\end{array}$} & \multirow{2}{*}{$\begin{array}{l}\text { Annual } \\
\text { rainfall } \\
(\mathrm{mm})\end{array}$} & \multirow{2}{*}{$\begin{array}{l}\text { Mean } \\
\mathrm{T}_{\text {air }}\left({ }^{\circ} \mathrm{C}\right)\end{array}$} & \multirow[t]{2}{*}{ Genotype } & \multirow{2}{*}{$\begin{array}{l}\text { Growth } \\
\text { cycle (n. of } \\
\text { days) }{ }^{b}\end{array}$} & \multicolumn{2}{|c|}{$\mathrm{ET}_{\mathrm{c}}(\mathrm{mm})$} & \multirow[t]{2}{*}{ Source } \\
\hline & & & & & Seasonal & Daily & \\
\hline $\begin{array}{l}\text { Alentejo, Portugal } \\
\text { (Mediterranean) }\end{array}$ & 550 & $10.0-25.0$ & 'Thompson', 'Crimson' & $160^{\mathrm{a}}$ & 626 & 3.9 & $\begin{array}{l}\text { Domingos et al. }(2015)^{\mathrm{a}} \text {, } \\
\text { Nóbrega }(2013)^{\mathrm{a}}, \\
\text { DGADR }(2015)\end{array}$ \\
\hline Zaragoza, Spain & 315 & $14.8-15.8$ & 'Crimson' & 196 & 778 & 4.0 & Faci et al. (2014), \\
\hline (Mediterranean) & & & 'Autumn R.' & 161 & 845 & 5.2 & $\begin{array}{l}\text { Suvočarev et al. } \\
\text { (2013) }\end{array}$ \\
\hline Apulia, Italy & 550 & 15.4 & 'Italia' & $130^{\mathrm{c}}$ & $277^{\mathrm{c}}$ & 2.1 & Tarricone et al. (2012, \\
\hline (Mediterranean) & & & 'Red globe' & $120^{\mathrm{c}}$ & $296^{\mathrm{c}}$ & 2.5 & $\begin{array}{l}\text { 2014) } \text {, Vanino et al. } \\
\text { (2015) }\end{array}$ \\
\hline A.Valley, Chile & $111-242$ & $9.4-22.4$ & 'Thompson' & 155 & $658-810$ & $4.2-5.2$ & Villagra et al. (2014), \\
\hline (Mediterranean) & & & 'Crimson' & 169 & 926 & 5.5 & $\begin{array}{l}\text { Zúniga-Espinoza et al. } \\
\text { (2015), Ferreyra et al. } \\
\text { (2006) }\end{array}$ \\
\hline $\begin{array}{l}\text { California, USA } \\
\text { (Mediterranean) }\end{array}$ & $190-410$ & $15.2-20.6$ & 'Thompson' & 190 & $718-865$ & $3.7-4.5$ & $\begin{array}{l}\text { Williams et al. (2003, } \\
\text { 2010), Williams } \\
\text { (2012) }\end{array}$ \\
\hline S. F.Valley, Brazil & $400-570$ & $24.0-30.0$ & 'Italia' & 120 & 503 & 4.2 & de Castro Teixeira et al. \\
\hline (Tropical semi-arid) & & & 'Superior' & $90-105$ & 390 & $3.7-4.3$ & $\begin{array}{l}\text { (1999), Teixeira et al. } \\
\text { (2007), Marinho et al. } \\
\text { (2009) }\end{array}$ \\
\hline Jales-SP, Brazil & 1334 & $20.7-25.5$ & 'Italia' & 150 & 330 & 2.2 & Conceição et al. (1998, \\
\hline (Tropical wet-dry) & & & 'Niágara R' & 130 & $299-325$ & $2.3-2.5$ & 2012) \\
\hline
\end{tabular}

${ }^{\mathrm{a}}$ Plastic covered in post "veraison", ${ }^{\mathrm{b}}$ bud break to harvest, ${ }^{\mathrm{c}}$ berry set to one week before harvest

industry must focus on optimizing irrigation water use. This involves increasing yield per cubic meter of water, or in more simpler terms, to obtain "more crop per drop" (Morison et al. 2008; Dodd 2009). The terms 'water productivity' or 'water use efficiencyWUE' translate the balance between gains (kg biomass produced or moles of assimilated carbon dioxide) and respective costs (number of cubic meters of water used or number of moles of transpired water vapour) (Medrano et al. 2010). Both terms are commonly used to evaluate the effect of irrigation strategies, including deficit irrigation. For eco-physiological purposes and related studies, the WUE refers to the ratio between net photosynthesis (An) and the transpiration rate $(\mathrm{E})$, namely the instantaneous WUE $\left(\mathrm{WUE}_{\text {instantaneous }}=\mathrm{An} / \mathrm{E}\right.$ ) or can also refer the ratio between An and stomatal conductance to water vapour (gs), which is defined as the intrinsic WUE (WUE in- $_{\text {- }}$ trinsic $=$ An/gs) $($ Medrano et al. 2010, 2015). The WUE can also be assessed at different time frames: at short term (calculated by instantaneous gas exchange measurements) or at long and more integrative term (carbon isotope ratio of dry matter of leaves) (Medrano et al. 2010).

For more agronomic purposes, the WUE at yield level (WUE $\mathrm{Wield}_{\mathrm{f}}$ ) is commonly adopted. WUE $\mathrm{W}_{\text {yield }}$ translates the ratio between total production of harvested yield and the total amount of water consumed by the crop (Medrano et al. 2010).

Deficit irrigation generally results in gains in both $\mathrm{WUE}_{\text {intrinsic }}$ and $\mathrm{WUE}_{\text {yield }}$ because under mild water stress conditions, photosynthesis is less negatively affected than E or gs (Medrano et al. 2010). Therefore, deficit irrigation can contribute to save water in irrigated table grapevine production. Deficit irrigation can be also a tool to influence berry quality as reported for wine grape (dos Santos et al. 2003; de Souza et al. 2005; Chaves et al. 2010). However, berry quality attributes for table grape differ from those considered for wine grape (Williams et al. 2010; Faci et al. 2014; Zúñiga-Espinoza et al. 2015; Conesa et al. 2016). As consequence, implementation of deficit irrigation strategies in table grape production may differ from those used in wine grape 

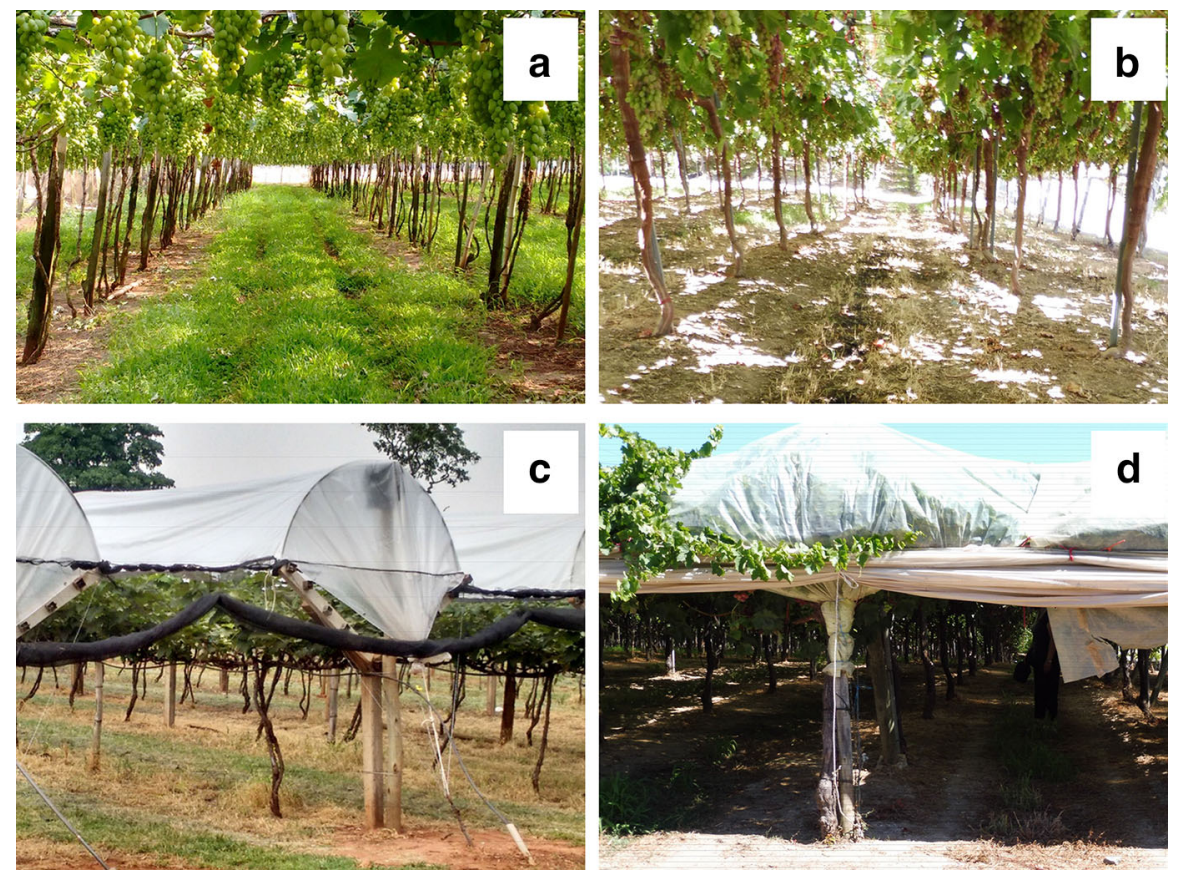

Fig. 1 View from a table grape vineyard in Brazil and Portugal. a Overhead trellis system at northwest of São Paulo State (tropical climate, $1334 \mathrm{~mm}$ annual precipitation), using microsprinkler irrigation and continuous resident vegetation on the inter-row; b overhead trellis system (Alentejo, South Portugal, Mediterranean climate, 450-600 $\mathrm{mm}$ annual precipitation),

production. This will be discussed in the following sections.

\subsection{Basic principles of deficit irrigation strategies}

A major characteristic of deficit irrigation strategies is to give enough water to stabilize yield, but enabling imposition of some degree of water deficit that permits to save irrigation water while controlling vigour and positively influencing quality (Fereres and Soriano 2007; Chaves et al. 2007; Costa et al. 2007; Geerts and Raes 2009). Deficit irrigation has been successfully applied to woody crops including grapevine (Escalona et al. 1999; Chaves et al. 2007; Medrano et al. 2015). The classic deficit irrigation strategy (DI) implies that water is supplied below full crop evapotranspiration $\left(\mathrm{ET}_{\mathrm{c}}\right)$ along the growing period. The two additional strategies are regulated deficit irrigation (RDI) and partial root drying (PRD) (English 1990; Chaves et al. 2007; Fereres and Soriano 2007). RDI is based on the fact that crop sensitivity to drought stress varies along the growth cycle and because intermittent water

using drip irrigation and dry resident vegetation on the interrow; c view of an Y-shaped plastic permanent covering system in the northwest of São Paulo State; and d horizontal trellis system covered with plastic during the ripening period at Alentejo, South Portugal

deficits during specific periods may benefit WUE, increase water savings and improve berry quality (McCarthy et al. 2002; Loveys et al. 2004; Cameron et al. 2006). By using the RDI strategy, plant water status can be maintained within certain limits of water deficit (with respect to maximum water potential) at specific phases of the crop cycle, normally when fruit growth is least sensitive to water reductions (Marsal et al. 2002; Kang and Zhang 2004). A major disadvantage of RDI however, is that plant's water status must be kept within narrow limits, which can be difficult to guarantee in field (due to climate variability) unless a rigorous plant/soil monitoring is performed. On the other hand, over-irrigation results in higher costs of water, energy and nutrients lixiviation, while less irrigation can cause major losses in yield and quality, mainly if abnormal and sudden high air temperatures (heat waves) are experienced (Jones 2004; Costa et al. 2012a; Lopes et al. 2014). In table grapes, RDI strategy is generally implemented in post-veraison phase, i.e. at the onset maturation, because reductions in watering before this stage can 
significantly decrease berry size and yield (Faci et al. 2014; Conesa et al. 2015).

Another deficit irrigation strategy tested in grapevine is PRD. This approach explores root exposure to alternate cycles of drying and wetting, which results in plants growing with reduced stomatal conductance to water vapour and without or with minimal signs of drought stress (Zhang et al. 1987; Davies et al. 1994; dos Santos et al. 2003; Kang and Zhang 2004; Dodd et al. 2006). PRD is based on plant root to shoot chemical signaling that influences shoot physiology and it can be operated in drip or furrow-irrigated crops. The theoretical basis of the PRD strategy is that the wet part of the root system will be kept with a favorable plant water status, while drying roots will increase abscisic acid (ABA) synthesis, which will reach leaves via the transpiration stream and induce stomatal closure (Kang and Zhang 2004; Dodd 2005). In parallel, PRD decreases vegetative growth and increases WUE (Dry and Loveys 1999; Davies et al. 2000; Chaves et al. 2007). The PRD strategy also promotes root growth at deeper soil layers in grapevine (Dry et al. 2000; Santos et al. 2005). PRD favors higher xylem $\mathrm{pH}$ and reduces cytokinin concentration (Davies and Zhang 1991; Dry and Loveys 1999; Stoll et al. 2000; Davies et al. 2005), which ultimately limits stomatal opening. PRD may influence carbohydrates partitioning among different plant organs and contribute positively to fruit quality (Kang and Zhang 2004). However, a practical inconvenient of PRD is that it requires double amount of tubes as compared to RDI or DI strategies, increasing installation and maintenance costs. Besides, literature reports conflicting results regarding the effects of PRD on the performance of several crops, including grapevine (Bravdo 2005; Chaves et al. 2010), which can be related to the soil type (e.g. fine texture soils will offer difficulties in a truly physical separation between dry and wet roots).

\subsection{Effects of deficit irrigation on water saving, WUE $_{\text {yield }}$ and agronomic performance of table grape}

Similarly to wine grape production (Chaves et al. 2010; Tomás et al. 2012; Costa et al. 2012b; Medrano et al. 2015) literature presents conflicting results for the effects of deficit irrigation on the performance of the table grape crop. Indeed, table grape responses to imposed mild to moderate water stress vary with the degree of soil water deficit, and the surrounding climate conditions (Tables 2, 3, 4). Moreover, the irrigation strategy (i.e. timing, duration and form/shape/mode, e.g. PRD) must account for the roles of the genotype that influence water uptake/transport (e.g. root, stem and leaf hydraulics, root and leaf morphology, leaf gas exchange behavior), as well as for the effect of agronomic practices (soil and canopy management).

Deficit irrigation (DI) can contribute to water savings in table grape production. Williams et al. (2010) studied the response of 'Thompson Seedless' vines under California conditions to different irrigation inputs (treatments ranging between 20 and $140 \%$ of $\mathrm{ET}_{\mathrm{c}}$ ). They found that maximum yields and berry weight increase were achieved when applying water at 60-80\% of $\mathrm{ET}_{\mathrm{c}}$. This means that values lower than $4000 \mathrm{~m}^{3} \mathrm{ha}^{-1}$ and greater than $8000 \mathrm{~m}^{3} \mathrm{ha}^{-1}$ did not guaranteed the best berry weight, yield, cluster number nor $W_{\text {Uield }}$ (Williams et al. 2010). Other studies show that the simple reduction in the irrigation threshold in terms of $\mathrm{ET}_{\mathrm{c}}(70-80 \%)$ or the irrigation arrest 13-21 days before harvest saved considerable amount of water, varying between a minimum of $300 \mathrm{~m}^{3} \mathrm{ha}^{-1}$ (Marinho et al. 2009; Conceição et al. 2014) and a maximum of $2400-3000 \mathrm{~m}^{3} \mathrm{ha}^{-1}$ per season (Serman et al. 2004; Conesa et al. 2015), while the influence on the yield and berry/cluster physical traits was minor or inexistent (see Table 3). In addition to water savings, we must account the potential economical and environmental benefits related to energy savings due to reduced water pumping and pressurizing water distribution systems which involve major energy requirements, especially in regions characterized by water scarcity and semi-arid climates (Soto-García et al. 2013).

Among the entire set of yield and biophysical quality traits considered for table grape berries and clusters, number of commercial clusters, berry weight, berry size/diameter, color and firmness are the most affected by deficit irrigation (Table 3). However, the timing of stress imposition influences the final effect of deficit irrigation on yield, $\mathrm{WUE}_{\text {yield }}$ and berry quality. For example in South Africa, and under desert conditions (climate BWh Köppen-Geiger) Myburgh (2003) found that when subjecting vines of $\mathrm{cv}$. 'Sultanina' (syn. 'Thompson Seedless') to water deficits at earlier stages (bud break, before flowering and flowering to pea size) was more negative to yield 


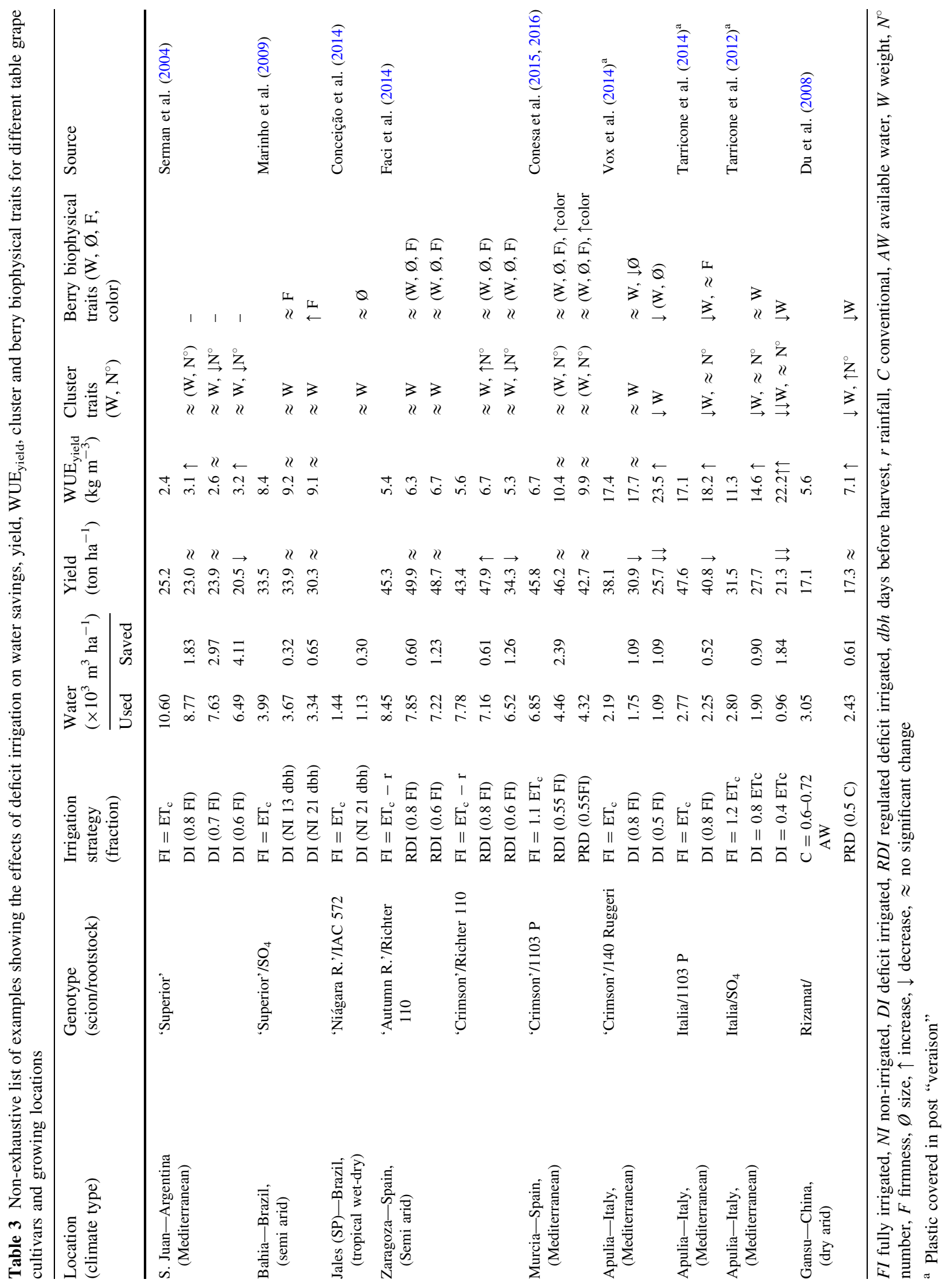


Table 4 Effects of deficit irrigation on berry biochemical traits for different table grape cultivars grown at different locations

\begin{tabular}{|c|c|c|c|c|}
\hline $\begin{array}{l}\text { Location } \\
\text { (climate type) }\end{array}$ & Genotype (scion/rootstock) & $\begin{array}{l}\text { Irrigation } \\
\text { (fraction) }\end{array}$ & Biochemical traits & Source \\
\hline $\begin{array}{l}\text { Bahia-Brazil, } \\
\text { (Semi arid) }\end{array}$ & 'Superior'/ $/ \mathrm{SO}_{4}$ & $\begin{array}{l}\text { FI = ETc } \\
\text { DI (NI 13-21 } \\
\text { dbh) }\end{array}$ & $\approx \mathrm{TSS}, \downarrow \mathrm{TA}$ & Marinho et al. (2009) \\
\hline $\begin{array}{l}\text { Jales (SP)—Brazil, } \\
\text { (Tropical wet-dry) }\end{array}$ & 'Niágara R.'/IAC 572 & $\begin{array}{l}\text { FI }=\text { ETc } \\
\text { DI (NI } 21 \\
\text { dbh) }\end{array}$ & $\approx(\mathrm{TSS}, \mathrm{pH})$ & $\begin{array}{l}\text { Conceição et al. } \\
\text { (2014) }\end{array}$ \\
\hline $\begin{array}{l}\text { Zaragoza-Spain, } \\
\text { (Semi arid) }\end{array}$ & $\begin{array}{l}\text { 'Autumn R.' and 'Crimson'/ } \\
\text { Richter } 110\end{array}$ & $\begin{array}{l}\mathrm{FI}=\mathrm{ETc}-\mathrm{r} \\
\mathrm{RDI}(0.8 \mathrm{FI}) \\
\mathrm{RDI}(0.6)\end{array}$ & $\begin{array}{l}\approx(\mathrm{TSS}, \mathrm{pH}) \\
\approx(\mathrm{TSS}, \mathrm{pH})\end{array}$ & Faci et al. (2014) \\
\hline $\begin{array}{l}\text { Murcia-Spain, } \\
\text { (Mediterranean) }\end{array}$ & 'Crimson'/1103 P & $\begin{array}{l}\mathrm{FI}=1.1 \mathrm{ETc} \\
\mathrm{RDI}(0.55 \mathrm{FI}) \\
\text { PRD }(0.55 \mathrm{FI})\end{array}$ & $\begin{array}{l}\approx(\mathrm{TSS}, \mathrm{TA}, \mathrm{F} 3-\mathrm{ol}, \mathrm{Res}), \\
\quad \downarrow(\mathrm{pH}, \mathrm{Fls}), \uparrow \mathrm{As} \\
\approx(\mathrm{TSS}, \mathrm{TA}, \mathrm{pH}, \mathrm{Fls}), \uparrow(\mathrm{F} 3- \\
\quad \mathrm{ol}, \mathrm{Res}), \uparrow \uparrow \mathrm{As}\end{array}$ & Conesa et al. (2016) \\
\hline $\begin{array}{l}\text { Apulia-Italy, } \\
\text { (Mediterranean) }\end{array}$ & 'Crimson'/140 Ruggeri & $\begin{array}{l}\mathrm{FI}=\mathrm{ETc} \\
\mathrm{DI}(0.8 \mathrm{FI}) \\
\mathrm{DI}(0.5 \mathrm{FI})\end{array}$ & $\begin{array}{l}\approx \mathrm{pH}, \uparrow(\mathrm{TSS}, \mathrm{TA}) \\
\approx(\mathrm{TA}, \mathrm{pH}), \uparrow \uparrow \mathrm{TSS}\end{array}$ & Vox et al. $(2014)^{\mathrm{a}}$ \\
\hline $\begin{array}{l}\text { Apulia-Italy, } \\
\text { (Mediterranean) }\end{array}$ & 'Italia'/1103 P & $\begin{array}{l}\mathrm{FI}=\mathrm{ETc} \\
\mathrm{DI}(0.8 \mathrm{FI})\end{array}$ & $\approx(\mathrm{TA}, \mathrm{pH}), \downarrow \mathrm{TSS}$ & $\begin{array}{l}\text { Tarricone et al. } \\
(2014)^{\mathrm{a}}\end{array}$ \\
\hline $\begin{array}{l}\text { Apulia-Italy, } \\
\text { (Mediterranean) }\end{array}$ & 'Italia' $/ \mathrm{SO}_{4}$ & $\begin{array}{l}\mathrm{FI}=1.2 \mathrm{ETc} \\
\mathrm{DI}=0.8 \mathrm{ETc} \\
\mathrm{DI}=0.4 \mathrm{ETc}\end{array}$ & $\begin{array}{l}\approx(\mathrm{TSS}, \mathrm{TA}, \mathrm{pH}) \\
\approx(\mathrm{TA}, \mathrm{pH}), \uparrow \mathrm{TSS}\end{array}$ & $\begin{array}{l}\text { Tarricone et al. } \\
(2012)^{\mathrm{a}}\end{array}$ \\
\hline $\begin{array}{l}\text { Gansu-China, } \\
\text { (Dry arid) }\end{array}$ & 'Rizamat'/ & $\begin{array}{l}\mathrm{C}=0.6-0.72 \\
\mathrm{AW} \\
\mathrm{PRD}(0.5 \mathrm{C})\end{array}$ & $\mathrm{TSS}, \downarrow \mathrm{TA}, \uparrow \mathrm{MI}, \uparrow \mathrm{Vc}$ & Du et al. (2008) \\
\hline $\begin{array}{l}\text { Okayama-Japan, } \\
\text { (Polyhouse) }\end{array}$ & 'Muscat of Alexandria'/ $/ \mathrm{SO}_{4}$ & $\begin{array}{l}\text { FI } \\
\text { RDI } \\
\text { PRD }\end{array}$ & $\begin{array}{l}\approx \mathrm{TA}, \uparrow(\mathrm{TSS}, \text { Amino acids) } \\
\approx \text { (TA, TSS, Amino acids) }\end{array}$ & $\begin{array}{l}\text { El-Ansary and } \\
\text { Okamoto (2008) }\end{array}$ \\
\hline
\end{tabular}

$\overline{F I}$ fully irrigated, NI non-irrigated, DI deficit irrigated, RDI regulated deficit irrigated, dbh days before harvest, $r$ rainfall, $C$ conventional, $A W$ available water, TSS total soluble solids, TA titratable acidity, F3-ol flavan-3-ols, Res resveratrol, Fls flavonols, As anthocyanins, $M I$ maturity index $=\mathrm{TSS} / \mathrm{TA} \times 10, V c$ Vitamin $\mathrm{C}$ content, $\uparrow$ increase, $\downarrow$ decrease, $\approx$ no significant change

a Plastic covered in post "veraison"

(decrease of 17, 15 and $9 \%$ respectively) than when imposing water deficits at pea size or at ripening (decrease of $4 \%$ as compared to not stressed vines). Moreover, there is a great variation in the response to DI among different genotypes (scion and rootstock), which can be related with the size of canopy, the length of the growth cycle, root traits (use or not of rootstock) and differences in climate and soil characteristics due to different location of trials (Table 3).

In Chile, Ferreyra et al. (2006) studied the effect of DI on the cv. 'Crimson Seedless' grown under the mild Mediterranean climate conditions (Csb Köppen-
Geiger) of Valparaiso Region. They found that DI (at $75 \% \mathrm{ET}_{\mathrm{c}}$ ) along crop cycle caused yield loss as compared to fully irrigated (FI) vines and saved $2800 \mathrm{~m}^{3} \mathrm{ha}^{-1}$ of irrigation water along the season. In Italy, and under typical Mediterranean climate conditions, Vox et al. (2014) found for the cv. 'Crimson Seedless' that imposing DI (at $80 \% \mathrm{ET}_{\mathrm{c}}$ ) after berry set decreased yield, berry size, did not affect $\mathrm{WUE}_{\text {yield }}$ $\left(17.7 \mathrm{~kg} \mathrm{~m}^{-3}\right)$ and enable water savings $\left(400 \mathrm{~m}^{3} \mathrm{ha}^{-1}\right)$ (Table 3).

Serman et al. (2004) observed for the cv. 'Superior Seedless' grown under a Mediterranean climate type 
that 70 and $100 \% \mathrm{ET}_{\mathrm{c}}$ irrigation treatments resulted in similar yield, and in a reduction of $3000 \mathrm{~m}^{3} \mathrm{ha}^{-1}$ of irrigation water and an increase of $\mathrm{WUE}_{\text {yield }}$ from 2.4 to $3.1 \mathrm{~kg} \mathrm{~m}^{-3}$ (Table 3). However, the number of commercial clusters per plant was reduced under 60-70\% $\mathrm{ET}_{\mathrm{c}}$ treatments (8-13 clusters per plant, respectively, as compared to 20-25 clusters for the $80-100 \% \mathrm{ET}_{\mathrm{c}}$ treatment) revealing the sensitivity of this cv. to deficit irrigation.

Other studies point out that imposing mild stress via RDI at post-veraison or for a short period (13-21 days) before harvest, resulted in higher or similar yields, no changes in $\mathrm{WUE}_{\text {yield }}$ and minor losses in the biophysical quality of the cluster (Table 3). However, when imposing stress at preveraison (after berry set), yield and cluster or berry quality was decreased (Vox et al. 2014; Tarricone et al. 2012, 2014) (Table 3).

Furthermore, Gálvez et al. (2014) tested the implementation of deficit irrigation controlled on the basis of stem water potential and vapor pressure deficit (VPD) in the cvs 'Red globe' and 'Thompson Seedless'. Water use under DI was reduced in the cv. 'Red globe' by about $5620 \mathrm{~m}^{3} \mathrm{ha}^{-1}$ per season as compared to conventional irrigation. In turn, water savings for the cv. 'Thompson Seedless' were only $487 \mathrm{~m}^{3} \mathrm{ha}^{-1}$. Nevertheless authors found no losses in yield nor in cluster quality in both cvs. The increase in WUE $_{\text {yield }}$ observed for the cv. 'Red globe' from 4.4 to $9.8 \mathrm{~kg} \mathrm{~m}^{-3}$ was more pronounced than the increase registered for the cv. 'Thompson Seedless' (from 2.9 to $3.1 \mathrm{~kg} \mathrm{~m}^{-3}$ ). This could be attributed to different vigor (canopy size) because the percentage of shaded area in the cv. 'Thompson Seedless' (i.e. $80 \%$ ) was larger than that of cv. 'Red Globe' (i.e. $70 \%$ ), or yet, to lower soil water availability as observed for the $\mathrm{cv}$. 'Thompson Seedless' (Gálvez et al. 2014).

Literature also describes the effect of PRD strategy on table grape production (Van Zyl 2007; Du et al. 2008; El-Ansary and Okamoto 2008). El-Ansary and Okamoto (2008) compared the effects of PRD and RDI irrigation strategies on vines of cv. 'Muscat of Alexandria' under greenhouse conditions. Their findings show that PRD and RDI treatments had the highest $\mathrm{WUE}_{\text {in- }}$ trinsic, with similar berry size and firmness in PRD, while these parameters were reduced in the RDI as compared to the control. In turn, Conesa et al. (2015) found that vines of the cv. 'Crimson Seedless' subjected to PRD and RDI treatments had similar $\mathrm{WUE}_{\text {yield }}$, berry size and firmness relatively to FI, but also improved berry color which is an important qualitative berry trait for this cv. (Table 3). In China, Du et al. (2008) evaluated the effects of PRD strategy in the cv. 'Rizamat'. PRD increased $\mathrm{WUE}_{\text {yield }}$ without losses in yield, but they found that PRD decreased berry and cluster weight (Table 3). In more recent trial, Du et al. (2013) studied the PRD principle under furrow irrigation conditions. Two treatments were tested: conventional furrow irrigation (control) and alternate partial root-zone furrow irrigation $\left(\mathrm{PRD}_{\text {furrow }}\right)$. Vines subjected to the $\mathrm{PRD}_{\text {furrow }}$ maintained net photosynthetic rates similar to the control but showed reduced transpiration. As a

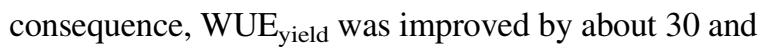
$13 \%$ in 2005 and 2006 respectively. In addition, $\mathrm{PRD}_{\text {furrow }}$ resulted in an increase of 2.9-4.8\% in berry edible percentage in both years.

Summarizing, successful implementation of deficit irrigation in table grape requires good knowledge on genotype behaviour and on environmental conditions (soil and air). Precise stress monitoring can help to optimize cultivation and irrigation scheduling and minimize the negative effects of mild water stress on yield and berry/cluster biophysical quality. In addition, modulation of irrigation along the season must be performed according to the vine's genotype, phenological stage and soil characteristics (physical traits influencing water relations i.e. soil texture) (See Sect. 3 for more details).

\subsection{Effects of deficit irrigation on berry metabolism and quality}

Table grape quality is evaluated not only on the basis of biophysical traits (see above) but also on the internal biochemical parameters. In addition to size, firmness and color, the acidity and the contents in total soluble solids (TSS) are the most important traits influencing berry quality (Serman et al. 2004; Williams et al. 2010; Champa 2015; Conesa et al. 2015). Fruit quality in table grape depends largely on the harvest date which mainly depends on the TSS that should vary between 14 and $17.5^{\circ}$ Brix, although this depends on the cv. and terroir (Codex Standard 2011; Ritschel et al. 2015; Champa 2015). A high TSS/TA ratio $(\mathrm{TA}=$ titratable acidity, measured with reference to tartaric acid) is another well accepted biochemical trait used to evaluate berry quality of table grape (Champa 2015). 
The majority of studies on table grapes describe the TSS, TA and $\mathrm{pH}$ as internal berry traits mostly influenced by deficit irrigation (Table 4). However, the effect of deficit irrigation strategies on these berry traits is not linear, and depends on the genotype, climate, and growing conditions (Table 4).

Berry biochemical quality is the final result of berry metabolism (carbon, nitrogen, hormones) and of a balanced accumulation of primary and secondary compounds e.g. sugars, organic acids, amino acids, anthocyanins, proanthocyanins, terpenoids and volatiles (Kuhn et al. 2014; Conde et al. 2015). Carbon metabolism at the leaf level has an important role on berry composition and final berry quality because leaf sugars correlate with anthocyanins accumulation (Dai et al. 2013; Kuhn et al. 2014). Sugar composition and concentrations depend on the genotype and the growing conditions, namely in terms of soil water availability (Dai et al. 2011). In general, water deficits increase the contents of sugars and stilbenoids in berries as compared to irrigated vines (Chaves et al. 2010; Zarrouk et al. 2016). The positive effect of mild water stress on the accumulation of secondary compounds (e.g. anthocyanins) relates with two major processes: (i) inhibition of berry development via preveraison water deficit (Koundouras et al. 2009; Basile et al. 2011; Intrigliolo et al. 2012) leading to accelerated berry ripening (Castellarin et al. 2007a, b) or (ii) increased proportion of seeds and skin relative to the whole-berry fresh mass by imposing post-veraison water stress (Roby and Matthews 2004).

El-Ansary and Okamoto (2008) found that fruits of the cv. 'Muscat of Alexandria' grown in a polyhouse (protected cultivation) under RDI conditions had higher contents in TSS, fructose, amino acids and aromatic volatile compounds, and lower concentration of malate at harvest than control vines. Du et al. (2008) in turn, working with cv. 'Rizamat' found that PRD caused no losses in berry quality, and that increased concentrations of ascorbic acid, TSS and decreased acidity (TA) contributed to healthier and sweeter berries. More recently, studies with the cv. 'Crimson Seedless' also showed that PRD increased berry's content in resveratrol in parallel whit an increase of flavonols and anthocyanins (Conesa et al. 2016) (Table 4).

Imposed water deficit changes berry growth and accelerate ripening via up-regulation of several genes controlling flavonoids pathway (Castellarin et al. 2007a, b). Koundouras et al. (2009) observed for vines of 'Cabernet Sauvignon' subjected to DI (50\% of $\mathrm{ET}_{\mathrm{c}}$ ) an increase of flavour at harvest and that preveraison drought stress promotes the accumulation of anthocyanins in berries.

The increase of sugars, anthocyanins and flavor compounds in berries in response to pre- or postveraison water deficits may be related with the promotive effects of ABA on fruit ripening (Ferrandino and Lovisolo 2014; Conesa et al. 2015). Indeed, ABA influences regulation of the biosynthesis of primary and secondary metabolites in berries (Davies et al. 1997; Antolín et al. 2003; Peppi et al. 2008; Deluc et al. 2009). Niculcea et al. (2014) observed for two wine grape cvs ('Tempranillo' and 'Graciano') that by imposing RDI $\left(40 \% \mathrm{ET}_{\mathrm{c}}\right)$ at pre- and post-veraison modified ABA accumulation patterns and extended the synthesis of $\mathrm{ABA}$ over time in the post-veraison treated berries resulting in higher concentration of sugars, phenolics and anthocyanins. Other hormones were also affected by deficit irrigation. For example early imposition of RDI markedly decreased auxins (IAA) and jasmonic acid (Niculcea et al. 2014).

The effects of deficit irrigation on berry biochemical traits largely depend on soil and atmospheric conditions along the growing cycle (Chaves et al. 2010; Shellie 2011). High $\mathrm{T}_{\text {air }}$ at mid-ripening coupled to DI $\left(25 \%\right.$ of $\left.\mathrm{ET}_{\mathrm{c}}\right)$ reduced total anthocyanins content, possibly by promoting degradation of these compounds or/and inhibition of their biosynthesis (Fernandes de Oliveira and Nieddu 2013). On the other hand, Bonada et al. (2013) found that the combination of soil water deficits and high $\mathrm{T}_{\text {air }}$ modifies the onset of berry net water loss and hastens ripening. This agrees with the fact that severe water stress reduces accumulation of anthocyanin compounds (Fernandes de Oliveira and Nieddu 2013; Zarrouk et al. 2016).

Other relevant point to clarify in table grape quality is to assess to what extent excessive irrigation and light exclusion (or too low light intensities) influence berry metabolism and ultimately berry quality at harvest and post-harvest. This is particularly relevant if we consider cultivation under plastic (see Sect. 3.3). Excessive irrigation and light exclusion can result in delayed or reduced sugar accumulation and increased TA together with a decrease in anthocyanin content, partly related to excessive shoot growth which increases shadowing of berry clusters (Deluc et al. 2009). 


\section{Complementary crop management tools}

\subsection{Genotypes (scion and rootstock)}

Grapevine (Vitis sp.) has large genetic variability (Chaves et al. 2010; Tomás et al. 2014), which leads to heterogeneous plant phenotypes in terms of vigour, yield, leaf and berry traits, and which will ultimately result in variation on plant demands on water, nutrients and/or in the responses to light, $\mathrm{T}_{\text {air }}$ or to water stress. Some of the most important differences existing among grapevine genotypes relate to morphophysiological and bio-physical traits such as leaf and root morphology, root and canopy architecture, leaf gas exchange, temperature regulation, hydraulics, hormones, osmotic adjustment capacity and phenology (short vs long growth cycle) (Chaves et al. 2010; Costa et al. 2012b; Kuhn et al. 2014; Tomás et al. 2014; Bota et al. 2016).

Genotype differences for drought tolerance are likely due to differences in root to shoot hormonal signaling, hydraulic regulation or metabolic activity related to hormones and/or nitrogen (Soar et al. 2006; Chaves et al. 2010; Hochberg et al. 2013). It is known that the ability to control ABA metabolism in leaves and fruits under stress differs among genotypes (Deluc et al. 2009; Chaves et al. 2010; Kuhn et al. 2014; Niculcea et al. 2014). Identically, grapevine genotypes respond differently to water stress in terms of leaf gas

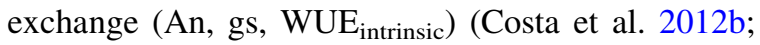
Tomás et al. 2014), and as consequence, they tend to respond differently to deficit irrigation.

The large biodiversity of grapevine is an opportunity to identify and select scion and rootstock genotypes better adapted to abiotic and biotic stress or to select the optimal combination of scion and rootstock genotypes to be grown under specific environments (e.g. hot and dry Mediterranean, tropical and semi-arid climates) (Carbonell-Bejerano et al. 2016). Indeed, rootstocks influence scions namely in terms of hydraulics and water uptake/transport, leaf gas exchange, vigour (Soar et al. 2006; Berdeja et al. 2015; Galbignani et al. 2016; Ollat et al. 2016) and berry quality (Cortell et al. 2007). As consequence, selection of rootstocks for higher tolerance to drought will improve adaptation of table grapes to more severe droughts as described for wine grapes (Berdeja et al. 2015) and it will help to improve berry quality. Selection of scion genotypes for semi arid climates should consider a compromise between higher WUE and leaf cooling capacity, as pointed out for wine grapes grown in dry and warm climates (Costa et al. 2012a, 2016). Leaf temperature regulation under stress conditions is crucial for optimal leaf photosynthesis and to avoid leaf damage, especially under heat waves events. Optimal leaf temperatures for grapevine photosynthesis vary between 25 and $30{ }^{\circ} \mathrm{C}$ (Greer 2012), but this range may depend on the genotype and the environmental conditions (Chaves et al. 2010).

In terms of genetic variability previous studies show a considerable variation in $\mathrm{WUE}_{\text {intrinsic }}$ between scion cultivars under irrigation conditions, ranging from $17.8 \mu \mathrm{mol} \mathrm{CO} \mathrm{mol}^{-1} \mathrm{H}_{2} \mathrm{O}$ in 'Sharad Seedless' to $110 \mu \mathrm{mol} \mathrm{CO}_{2} \mathrm{~mol}^{-1} \mathrm{H}_{2} \mathrm{O}$ measured in cv. 'Rosaki' or under dry conditions, in which the cv. 'Tas-AGanesh' (mutant of the cv. 'Thompson Seedless') featured a minimum of $16 \mu \mathrm{mol} \mathrm{CO}_{2} \mathrm{~mol}^{-1} \mathrm{H}_{2} \mathrm{O}$, whereas a maximum of $200 \mu \mathrm{mol} \mathrm{CO} \mathrm{Col}^{-1} \mathrm{H}_{2} \mathrm{O}$ was measured for the cv. 'Rosaki' (Medrano et al. 2015).

Identically, the existing variability in rootstock genotypes should be considered for breeding and selection purposes. Variability for traits such as suitability for propagation (e.g. grafting compatibility, rooting ability), resistance/tolerance to abiotic and/or biotic stress (e.g. tolerance to lime and to salinity and drought) are important traits to be studied and improved in novel genotypes (Granett et al. 2001; Satisha et al. 2006;2007; Serra et al. 2014).

Satisha and Prakash (2006) found substantial variation for $\mathrm{WUE}_{\text {intrinsic }}$ among three scion cultivars ('Flame Seedless', 'Thompson Seedless', 'Sharad Seedless') grafted on three different rootstocks ('Dog Ridge', 'Salt Creek' and 'Vitis champinii or $V C$ clone'), and under $50 \%$ moisture stress. The use of the 'Dog Ridge' rootstock resulted in the highest

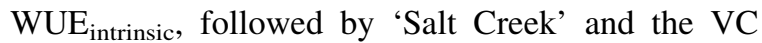
clone. Among the scion varieties, the cv. 'Flame Seedless' had the highest $\mathrm{WUE}_{\text {intrinsic }}(15-25.2 \mu \mathrm{mol}$ $\left.\mathrm{CO}_{2} \mathrm{~mol}^{-1} \mathrm{H}_{2} \mathrm{O}\right)$ followed by 'Sharad Seedless' (16-22.3 $\mu \mathrm{mol} \mathrm{CO}_{2} \mathrm{~mol}^{-1} \mathrm{H}_{2} \mathrm{O}$ ) and 'Thompson Seedless' (14.1-17.7 $\mu \mathrm{mol} \mathrm{CO} \mathrm{mol}^{-1} \mathrm{H}_{2} \mathrm{O}$ ) under $50 \%$ moisture stress conditions. 'Dog Ridge' and 'Salt Creek' rootstocks influenced positively An and WUE $_{\text {intrinsic }}$ of cv. 'Flame Seedless' and 'Sharad Seedless' under drought conditions.

Rootstocks influence scion vigour and some studies suggest that this can be due to xylem hydraulic 
a

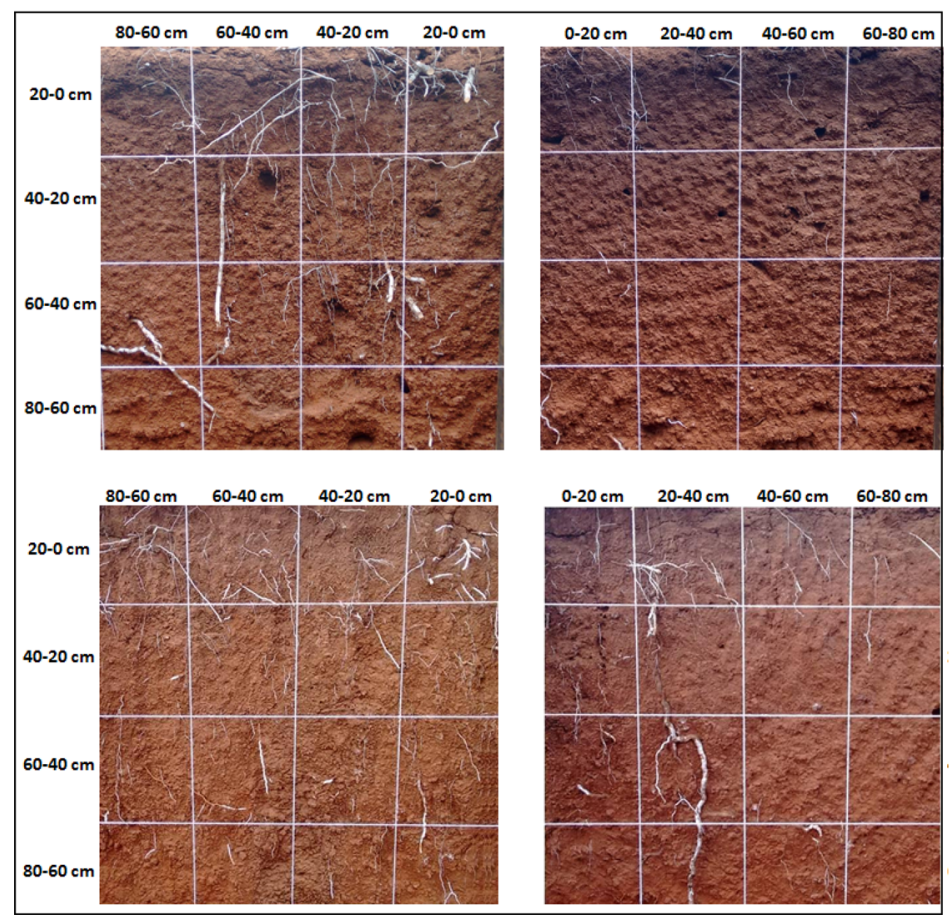

b

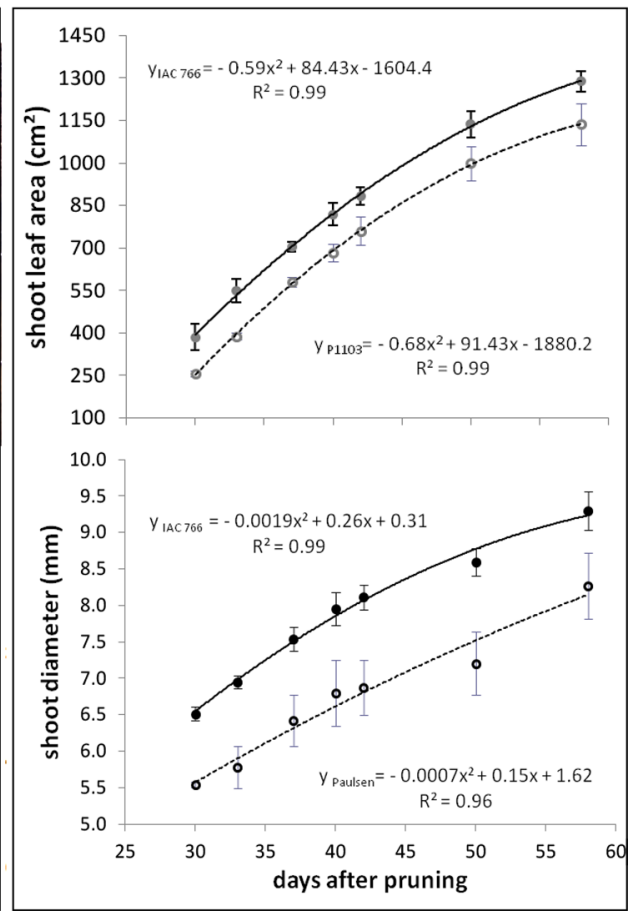

Fig. 2 Effects of scion/rootstock combination on root and shoot traits for plants of the seedless table grape cv. 'BRS Vitoria' with 3 year old, grown in northwest of São Paulo state under irrigated conditions. a Rooting distribution in grafted plants using the rootstocks 'IAC-766' (top) and the rootstock

function. High vigour would be linked to larger hydraulic conductance of the whole-root-system (Alsina et al. 2011; Gambetta et al. 2012; Tramontini et al. 2013). In the northwest region of São Paulo state, Brazil, the rootstock 'IAC 766' was compared with '1103 Paulsen', using as scion the novel seedless cv. 'BRS Vitória', which it is tolerant to downy mildew, and simultaneously vigorous (large canopy) under irrigated conditions (Permanhani et al., unpublished results). The 'IAC 766' rootstock showed to regulate better shoot vigour and permitted a more balanced vegetative and reproductive growth of the cv. 'BRS Vitória', than the '1103 Paulsen' rootstock (Fig. 2).

Less vigorous scion varieties can adapt better to dryer areas due to their smaller canopy size which minimizes evaporative water losses. Moreover, smaller or narrower leaves will reach lower peak surface temperatures than will larger ones due to the thinner boundary layer and improved convective dissipation (Vogel 2009). This is an advantage under dry and hot conditions or if protected cultivation is adopted.
'1103 Paulsen' (bottom). b Average shoot leaf area (top) and shoot diameter (bottom) measured 30-60 days after pruning in 2014, for plants on rootstock 'IAC-766' (solid line) and '1103 Paulsen' (dashed line). Points indicate means and vertical bars indicate SE $(n=16)$ (Permanhani et al., unpublished results)

Another important aspect related to the genotype is the capacity of plants to recover from stress. Indeed research of water stress-recovery cycles/responses is an important component of grapevine eco-physiology (see Flexas et al. 2009; Santesteban et al. 2009; Bondada and Shutthanandan 2012). This because drought induces xylem embolism formation and the vulnerability or ability to repair embolized vessels to restore xylem functionality may differ between genotypes or species (Lovisolo et al. 2008; Knipfer et al. 2015).

\subsection{Precise monitoring of crop performance and soil/microclimate condition}

Modern and more sustainable table grape production demands methods to obtain robust data on crop's morpho-physiology (roots, canopy and berry), soil and microclimate conditions, in a fast and remote way. Precision agriculture and viticulture experienced fast developments in the recent decades (Bastiaanssen 
et al. 2008; Gago et al. 2015; Matese and Di Gennaro 2015; Jones and Grant 2016; Grant et al. 2016). The basic aim is to combine different tools to gather more data to support faster and robust decision-making process, and to increase input use efficiency (e.g. water, fertilizers, biocides) and to minimize environmental burdens (e.g. soil and water pollution).

Recorded parameters such as $\mathrm{T}_{\text {air }}$ and VPD, soil water content, total irradiance are commonly required to estimate plant needs and support irrigation management. For example, Allen et al. (1998) established that soil water depletion greater than $30 \%$ of the available soil water is a critical point for table grapes although it varies with soil type and atmospheric conditions ( $\left.\mathrm{T}_{\text {air }}, \mathrm{VPD}\right)$. Several parameters to assess vine's water status have been used in table grape production namely trunk diameter variation (TDV), berry growth, leaf/stem water potential and leaf temperature (Avidan et al. 2005; Kopyt and Ton 2005; Gálvez et al. 2014). The TDV allows an early and quantitative detection of vine's response to soil water availability during the vegetative and reproductive growth but the variation coefficients can be larger than the ones obtained for water potential (SilvaContreras et al. 2012). Besides, TDV installation is complex, it is prone to maintenance problems and provides too localized information of the vineyard, missing its spatial variability.

Berry diameter is a sensitive indicator of water stress. Zhang et al. (2012) observed that berry diameter increased at night and decreased during the day, when soil water potential (SWP) varied between -3 to $-5.4 \mathrm{kPa}$, and beyond, berry began to shrink, while photosynthesis and transpiration remain unaffected until SWP became $-9.3 \mathrm{kPa}$ or less. Measurement of leaf water potential (at predawn and/or midday) has been adopted as a robust tool to monitor vines' water status and to program irrigation namely in combination with remote sensing of canopy temperature (Cohen et al. 2005; Bellvert et al. 2013; Lopes et al. 2014; Grant et al. 2016).

Modern viticulture experienced significant progress in the last decades, namely due to a shift towards more precise and site specific crop management, taking into account both soil and crop heterogeneities existing in the field. Non-invasive imaging and computer vision approaches provide nowadays another tool to correctly estimate within-field variability, potential crop needs, and potential yield (Bastiaannsen et al. 2008; Fiorani et al. 2012; Jones and Grant 2016). Remote sensing is based on the detection of different spectral wavelengths emitted or reflected by the crop and soil and can provide in real time quantitative and spatial information on plant and soil condition (e.g. water status, growth).

The typical row system cultivation makes easier to use remote sensing and related imaging systems in the vineyards. However, their use is still being tested and validated due to the complexity of grapevine's canopy and root systems (Ciraolo et al. 2012). Furthermore, environmental conditions disturb measurements which requires careful set up, calibration and the use of indexes to minimize the variation related to environment effects (e.g. use thermal indexes in thermal imaging measurements) (Jones 2004; Bellvert et al. 2013; Costa et al. 2013; Grant et al. 2016).

In the case of table grape production, the use of ground and aerial based imaging may be restricted attending if we consider the complex wood/metal structures and the use of protected cultivation at least during part of the growing cycle (Fig. 1). Vegetation indices such as the Normalized Difference Vegetation Index (NDVI) were the basis for many remote sensing applications to crop management because they correlate well with plant's green biomass and canopy leaf area index (Jones and Vaughan 2010; Jones and Grant 2016). Recently, satellite-based assessments of irrigation performance by table grapes on the basis of NDVI were described for vineyards in Australia (Whitfield et al. 2014).

We may also envisage the use of thermography in table grape to monitor soil and plant water status on the basis of soil and leaf/canopy surface temperatures. Nevertheless, studies on the topic are still few suggesting limitations posed by crop specificities (e.g. growing and training system, crop architecture) but also related to the costs of equipment and software and know-how on image capturing and processing.

Remote sensing can be also applied to berries. For example, technology based on visible imaging has been recently developed to remotely assess berry sun burn (Rustioni et al. 2014) and bunch compactness (Cubero et al. 2015) in wine grapes. Identically a image based interpretation tool to estimate number, diameter, and volume of grapevine berries (Berry Analysis Tool) has been developed (Kicherer et al. 2013). Identical type of approaches could be envisaged for table grapes. 


\subsection{Protected cultivation}

Protected cultivation is now a common procedure in table grape production in different regions and climates (e.g. Brazil and Portugal-Fig. 1c, d) and it has a major effect on crop's growth cycle, WUE, berry quality and diseases incidence. Vines can be covered with transparent plastic film or nets to protect foliage and fruits from meteorological adversities (e.g. wind, rain, frost, hail, sun radiation) and from damage cause by pests, diseases or birds (Novello and de Palma 2008; Roberto et al. 2011; Moratiel and Martínez-Cob 2012; Du et al. 2015).

Plastic covering increases $T_{\text {air }}$ which induces faster accumulation of growing degree days, stimulates precocious bud break (Novello and de Palma 2008; Suvočarev et al. 2013) and promotes early harvest (Kamiloğlu et al. 2011; Roberto et al. 2011). However, harvest can be also delayed by using protected cultivation, by increasing shading at beginning of fruit ripening (Novello and de Palma 2008; Roberto et al. 2011).

Ferreira et al. (2004) found that plastic covering did not anticipate the vegetative cycle of cv. 'Niagara Rosada' (Vitis labrusca) in southern Minas Gerais state-Southeast of Brazil (Cwb Köppen-Geiger), whereas Comiran et al. (2012) found for the same cv. grown under plastic in Rio Grande do Sul stateSouthern Brazil (Cfb Köppen-Geiger) a significant anticipation of plant phenology until ripening and delayed leaf senescence. This is in line with the findings of de Souza et al. (2015) who report higher leaf chlorophyll content for vines of the cv. 'Syrah' grown under plastic.

Regarding crop water use, Tarricone et al. (2014) showed in Apulia region (Southern Italy) that vines of the cv. 'Italia' covered with plastic film after 'veraison' and subjected to mild water stress (at $80 \%$ of $^{2} T_{c}$ ) from berry set to harvest allowed the best balance for growth, yield, berry quality, and WUE $E_{\text {yield }}\left(18 \mathrm{~kg} \mathrm{~m}^{-3}\right)$, with the possibility to save a maximum of $500 \mathrm{~m}^{3} \mathrm{ha}^{-1}$ water.

Netting is also relevant in table grape production. Netting is cheaper than plastic covering and has a positive effect on berry quality and water savings (Roberto et al. 2011; Suvočarev et al. 2013). Netting favors cooling of the canopy (Greer and Weedon 2013) and can help to prevent leaf/berry damage under high light intensities and heat waves, just like it may occur in Mediterranean conditions, in particular during summer time.
Rana et al. (2004) compared table grape vines (cv. 'Italia') grown under two covering strategies (thin net and plastic film) with uncovered vines in terms of their water requirements $\left(\mathrm{ET}_{\mathrm{c}}\right)$. The uncovered vines had high $\mathrm{ET}_{\mathrm{c}}\left(6.4 \mathrm{~mm}\right.$ day $\left.^{-1}\right)$ after irrigation. The $\mathrm{ET}_{\mathrm{c}}$ decreased rapidly until it reaches a minimum of about $4 \mathrm{~mm} \mathrm{day}^{-1}$ after 9 days. In covered vines the $\mathrm{ET}_{\mathrm{c}}$ was lower $\left(3 \mathrm{~mm} \mathrm{day}^{-1}\right)$ after irrigation and decreased very slow, taking 24 days to reach a minimum of $1.9 \mathrm{~mm} \mathrm{day}^{-1}$. In turn, plants covered with the thin net had an intermediate $\mathrm{ET}_{\mathrm{c}}$ value between the remaining two treatments.

Protected cultivation can increase WUE due to lower evapotranspiration losses as compared to open field conditions, similarly to what occurs in greenhouse horticulture (Stanghellini 2014). However, the use of plastics has disadvantages as well. If not properly managed, plastic covering can increase excessively $\mathrm{T}_{\text {air }}$, as well as leaf and berry temperatures due to inadequate air circulation (Liu et al. 2012) which is a risk for leaf condition and berry quality. In addition, installation costs are higher than open field production and plastic use can increase environmental burdens due to the generation of large amount of plastic waste and the difficulties in collecting and recycling it (Sica et al. 2015).

\subsection{Soil and canopy management strategies}

Soil characteristics (texture, water storage capacity), soil management (tillage, fertilization, mulching, cover cropping) (Fig. 1) as well as canopy and fruit management (i.e. pruning, leaf removal, shoot positioning, cluster thinning) are important aspects of modern table grape production. In fact, they influence plant vigor, cluster microclimate, yield, berry size and composition, and have a determinant impact on irrigation needs and management (Lanyon et al. 2004; Proffitt and Clause 2011; Strik 2011). We present further some examples. Weed control performed in vineyards of the cv. 'Niagara Rosada' in Brazil, saved irrigation water especially during the initial vegetative stages, between bud break and flowering (Conceição et al. 2012). For wine grape production, in a study carried out with the cv. 'Chardonnay', Curtis (2013) evaluated the effect of soil mulch based on residues of winter annual cover crops on soil moisture. The author found higher soil water content in the mulched soil along summer as 
compared to soil deprived of any mulch. Root density increased in soil mulching conditions as result of increased moisture and reduced soil mechanical resistance (Curtis 2013). Canopy management is essential for optimal light exposure, as well canopy temperature, crop load and berry color. Too low light intensities within the fruiting zone can reduce fruit color in red or black cvs (Peacock et al. 1994; Kuhn et al. 2014). In turn, light exclusion resulted in limited carbon supply that caused flower abortion and decreased fruit setting (Domingos et al. 2015). These responses vary with the genotype. In the high vigor cv. 'Thompson Seedless' low light intensity within the canopy and near the fruit zone showed to reduce bud formation. As consequence inadequately trellised vineyards contribute to bud fruitfulness, berry drop and yield loss. In addition, berry drop will favor diversion of assimilates to vegetative growth which will further decrease bud fruitfulness (Peacock et al. 1994).

Literature reports that upward or downward orientations of grapevine shoots may influence vine's hydraulic conductance and water transport, which in turn, negatively influences leaf gas exchange, growth and response to stress (Lovisolo and Schubert 2000). An adequate trellis system must be also considered as a strategy to minimize the impact of heat waves. In Australia vineyards with sprawling, non-positioned canopies showed the least heat damage, whereas the vertically shoot positioned (VSP) trellis was the most affected by heat damage (Hayman et al. 2012). In addition, changes in the distribution and total leaf area by defoliation, pruning and training modify canopy microclimate, increasing light interception and favouring crop's water demand (Reynolds and VandenHeuvel 2009). This is also described by Williams and Ayars (2005) for plants of the cv. 'Thompson Seedless', for which an increase in trellis height resulted in extra water consumption of 18 litres per plant.

\subsection{Use of low quality water}

Treated wastewater is becoming an increasingly valuable source of water for irrigation, especially in arid and semiarid regions of the world (Scheierling et al. 2011; Costa et al. 2016). However, the use of recycled wastewater in agriculture involves several questions, namely related to human health issues, salinity injury to plants and soil (Laurenson et al. 2012; Netzer et al. 2014). Moreover, combination of deficit irrigation with low water quality may end in excessive soil salinity, in particular under high evapotranspiration conditions that promote salt accumulation, and that will cause marked yield losses (Bravdo 2012; Aragüés et al. 2014).

Grapevine is moderately sensitive to soil salinity. The species has a threshold for electrical conductivity of the saturated soil paste extract (ECe) of $1.5 \mathrm{dS} \mathrm{m}^{-1}$ (Allen et al. 1998). However, the response of table grape to saline waters and soil salinity varies with the genotype (scion and rootstock) (Bravdo 2012; Zhang et al. 2002; Aragüés et al. 2014), soil type (Netzer et al. 2014) and irrigation strategies (Aragüés et al. 2014).

In a trial to test the effect of scion and rootstocks on salinity response, Zhang et al. (2002) found that the cv. 'Thompson Seedless' grafted on cv. 1103 'Paulsen' and the cv. 'R2' hybrid (V. champini vs V. berlandieri and $V$. vinifera) were the most salt-tolerant, and had no yield reduction until ECe was above $4 \mathrm{dS} \mathrm{m}^{-1}$. Soil type has also an influence on vine's response to low quality water and growers must consider in advance soil's physico-chemical properties. In areas characterized by saline soils or prone to flooding and salt accumulation, growers are forced to use excessive water applications to promote salt lixiviation (Lanyon et al. 2004). Clay soils, in turn, may present a faster build up of $\mathrm{Na}^{+}$and sodium adsorption ratio in the root zone with negative consequences for vines (Netzer et al. 2014). Irrigation strategies influence the effects of using saline waters in table grape production. Aragüés et al. (2014) tested the use of moderately saline water $\left(1.7 \mathrm{dS} \mathrm{m}^{-1}\right)$ in combination with RDI strategy in two cvs ('Autumn Royal' and 'Crimson Seedless') grafted onto the rootstock 'Richter 110' which is moderately tolerant to salinity. They found that ECe was high in 'Autumn Royal' $\left(4.4 \mathrm{dS} \mathrm{m}^{-1}\right.$ ) and very high in 'Crimson Seedless' $\left(7.0 \mathrm{dS} \mathrm{m}^{-1}\right)$ due to the relatively low leaching fractions $(0.20$ in 'Autumn Royal' and 0.13 in 'Crimson Seedless'). Moreover, soil solution salinity was higher under RDI $\left(60 \% \mathrm{ET}_{\mathrm{c}}\right)$ than under FI conditions suggesting that deficit irrigation involves more risks when growers irrigate with low quality water (Aragüés et al. 2014). Attending to the high $\mathrm{N}$ content of treated wastewaters, literature suggest the use of cover crops to remove the excess of nitrogen input (Weber et al. 2014). Nevertheless, the risks for human health posed by the use of treated wastewater must be better studied (Gerardi and Zimmerman 2005; Netzer 2010). 


\section{Future strategies for higher sustainability in table grape production}

Scarcer water resources and the ongoing climate change are two of the risks that table grape industry will face in many areas of the globe and which can negatively affect the environmental and economical sustainability of the sector. In addition, environmental regulations concerning the use of natural resources (soil, water) or other inputs (fertilizer and biocides) in intensive agriculture are becoming more strict (Gerling 2015; Ejsmentewicz et al. 2015; Costa et al. 2016). In fact, consumers and wholesalers are now more informed and demanding more sustainable agricultural products including commodities such as wine and table grapes (Gerling 2015; Costa et al. 2016).

Our review shows that deficit irrigation has potential to be used in table grape production, but variation is large in terms of the achieved yield, berry quality and WUE. Therefore, a careful and improved quantitative characterization of the role of genotypes (scions and rootstocks) in combination with deficit irrigation strategies is still needed. Identically, the sector needs to optimize irrigation management and scheduling at a certain phenological phase.

Fixed and localized sensors provide limited information due to the large variations in the response to water deficits of cultivars, soil type and heterogeneity (Zimmermann 2013). Therefore, it is desirable to integrate multiple monitoring approaches that encompass the use of ground and aerial remote monitoring. Implementing more efficient water saving procedures requires precise knowledge on environmental conditions (soil, air) (Table 2) and it strongly depends on the available technological capability and know-how (Levidow et al. 2014). Small scale growers face more limitations in accessing information and in terms of investment and innovation capability as compared to large companies. Novel technologies and irrigation approaches can help growers but it is still needed to develop cheaper and more user-friendly solutions to monitor vines and berries and support irrigation scheduling.

Using low quality water/(treated wastewater) involves the use of alternative irrigation/fertilization strategies (e.g. intervals) and improved water-soilplant quality control together with more strict quality certification and control. This makes the use of low quality water less feasible for countries with deficient control and certification mechanisms. Therefore, the use of recycled water will expand faster in countries where the reuse of water is already in place and at a more advanced stage, and where water prices tend to be higher and/or to rise faster (e.g. USA, Spain, Australia, Israel) (Netzer et al. 2009).

Another crucial aspect for future competitiveness of the sector is a robust water metrics. This is especially important for companies focusing on exporting markets and dealing with quality certification requirements by consumer markets. Water metrics and related account of the water use in the vineyard is essential to optimize the use of water resources. Many initiatives and programs for sustainable water use were adopted for wine grape production (Gerling 2015; Costa et al. 2016) but water use indicators and water use benchmarking is scarce or inexistent in table grape production.

Improved knowledge in the stress-physiology and agronomic performance of novel or existing varieties and rootstocks is needed. Breeding novel varieties and/or rootstocks will help to develop more resistant genotypes to heat and drought stress but also to salinity and/or low quality water. More research on berry metabolism and berry physical traits in response to water and heat stress is needed. Identically, integration of morpho-physiological and molecular data with modeling approaches can help to predict growth and quality. Recent research projects on grapevine such as the European INNOVINE are focused on sustainability and improved quality and showed advances in the domain of physiology of berry growth and modelling (INNOVINE 2015). Simulation of processes of fruit growth and sugar accumulation in terms of water and carbon balance could be also tested for table grapes. Other fluxes such as those of nitrogen and sulphur also effect berry quality and should be incorporated in models to predict berry quality in table grape, similarly to what is occurring for wine grape (INNOVINE 2015).

The increasing problems with fungal and bacterial diseases in grapevine and the demand for productive elite varieties more resistant to biotic and abiotic stresses puts an increasing pressure on breeders. Biotechnology has been emerging as a new tool for breeders and it may offer novel possibilities to obtain in faster way novel elite lines more resistant to stress and with improved WUE or berry traits as it is described for wine grape (Flexas et al. 2010). Nevertheless, we must still improve our knowledge on the potential of the 
available but still uncharacterized biodiversity (Carbonell-Bejerano et al. 2016), and develop more efficient phenotyping and selection procedures.

At market level, consumers are increasingly demanding better quality and more environmental certification. Therefore, future studies on table grape should focus on agronomic strategies to promote yield and quality and environmental sustainability at controlled costs for growers. Finally, making decisions in table grape production tends to depend more and more on benchmarking data (Swinburn 2014) which can be applied to yield and quality parameters but also to crop's water use.

Acknowledgments Miquéias Permanhani received support from CAPES Foundation - Proc. BEX 3665/15-1, Ministry of Education of Brazil, Brasília-DF, Brazil. JM Costa had a scholarship funded by Fundação para a Ciência e Tecnologia (ref. SFRH/BPD/93334/2013), Portugal. We thank as well the support from the Research unit GREEN-it "Bioresources for Sustainability" (UID/Multi/04551/2013) and the funding from European Community's Seventh Framework Programme (FP7/ 2007-2013) under the grant agreement n ${ }^{\circ}$ FP7-311775, Project INNOVINE.

\section{References}

Allen RG, Pereira LS, Raes D, Smith M (1998) FAO Irrigation and Drainage Paper No. 56. Crop Evapotranspiration. Guidelines for computing crop water requirements. FAO, Rome. ftp://biosfera.dea.ufv.br/gabriel/lue_teste/doc/fao56. pdf

Alsina MM, Smart DR, Bauerle T, de Herralde F, Biel C, Stockert C, Negron C, Save R (2011) Seasonal changes of whole root system conductance by a drought-tolerant grape root system. J Exp Bot 62:99-109

Antolín MC, Baigorri H, Luis ID et al (2003) ABA during reproductive development in non-irrigated grapevines (Vitis vinifera L. cv. Tempranillo). Aust J Grape Wine Res 9:169-176. doi:10.1111/j.1755-0238.2003.tb00266.x

Aragüés R, Medina ET, Clavería I et al (2014) Regulated deficit irrigation, soil salinization and soil solidification in a table grape vineyard drip-irrigated with moderately saline waters. Agric Water Manag 134:84-93. doi:10.1016/j. agwat.2013.11.019

ATGA (2015) Australian Table Grape Association Inc, Australian Grape Growing Areas. http://www.australiangrapes. com.au/__data/assets/pdf_file/0017/17225/HAL0462_ Grapes_Industry_Booklet.pdf

Avidan A, Hazan A, Kopyt M, Ton Y (2005) Application of the phytomonitoring technique for table grapes. In: Proceedings of the international workshop on advances in grapevine and wine research, Venosa

Basile B, Marsal J, Mata M et al (2011) Phenological sensitivity of cabernet sauvignon to water stress: vine physiology and berry composition. Am J Enol Vitic 62:452-461
Bastiaannsen WGM, Pelgrum H, Soppe RWO et al (2008) Thermal-infrared technology for local and regional scale irrigation analyses in horticultural systems. Acta Hortic 792:33-46. doi:10.17660/ActaHortic.2008.792.2

Bellvert J, Zarco-Tejada PJ, Gonzalez-Dugo V et al (2013) Scheduling vineyard irrigation based on mapping leaf water potential from airborne thermal imagery. In: Stafford JV (ed) Precision agriculture'13. Wageningen Academic Publishers, Wageningen, pp 699-704

Berdeja M, Nicolas P, Kappel C et al (2015) Water limitation and rootstock genotype interact to alter grape berry metabolism through transcriptome reprogramming. Hortic Res 2(15012):1-13. doi:10.1038/hortres.2015.12

Bonada M, Sadras V, Moran M, Fuentes S (2013) Elevated temperature and water stress accelerate mesocarp cell death and shrivelling, and decouple sensory traits in Shiraz berries. Irrig Sci 31:1317-1331. doi:10.1007/s00271-0130407-z

Bondada B, Shutthanandan J (2012) Understanding differential responses of grapevine (Vitis vinifera L.) leaf and fruit to water stress and recovery following re-watering. Am J Plant Sci 3(09):1232-1240

Bota J, Tomás M, Flexas J et al (2016) Differences among grapevine cultivars in their stomatal behavior and water use efficiency under progressive water stress. Agric Water Manag. doi:10.1016/j.agwat.2015.07.016

Bravdo BA (2005) Physiological mechanisms involved in the production of non-hydraulic root signals by partial rootzone drying-a review. Acta Hortic 689(267-276):2005. doi:10.17660/ActaHortic.2005.689.31

Bravdo B (2012) Effects of salinity and irrigation with desalinated effluent and sea water on production and fruit quality of grapevines (review and update). Acta Hortic 931: 245-258. doi:10.17660/ActaHortic.2012.931.27

Camargo U, Mandelli F, Conceição MAF, Tonietto J (2012) Grapevine performance and production strategies in tropical climates. As J Food Agro-Ind 5(04):257-269

Cameron KD, Teece MA, Smart LB (2006) Increased accumulation of cuticular wax and expression of lipid transfer protein in response to periodic drying events in leaves of tree tobacco. Plant Physiol 140:176-183. doi:10.1104/pp. 105.069724

Carbonell-Bejerano P, Carvalho LC, Eiras Dias JE et al (2016) Exploiting Vitis genetic diversity to manage with stress. In: Gerós H, Chaves M, Medrano H, Delrot S (eds) Grapevine in a changing environment: a molecular and ecophysiological perspective. Wiley-Blackwell, Hoboken, pp 347-380

Castellarin SD, Matthews MA, Di Gaspero G, Gambetta GA (2007a) Water deficits accelerate ripening and induce changes in gene expression regulating flavonoid biosynthesis in grape berries. Planta 227:101-112. doi:10.1007/ s00425-007-0598-8

Castellarin SD, Pfeiffer A, Sivilotti P et al (2007b) Transcriptional regulation of anthocyanin biosynthesis in ripening fruits of grapevine under seasonal water deficit. Plant, Cell Environ 30:1381-1399. doi:10.1111/j.1365-3040.2007. 01716.x

Champa W (2015) Pre and postharvest practices for quality improvement of table grapes (Vitis vinifera L.). Found Sri Lanka 43(1):3-9 
Chaves MM, Santos TP, Souza CR et al (2007) Deficit irrigation in grapevine improves water-use efficiency while controlling vigour and production quality. Ann Appl Biol 150:237-252. doi:10.1111/j.1744-7348.2006.00123.x

Chaves MM, Zarrouk O, Francisco R et al (2010) Grapevine under deficit irrigation: hints from physiological and molecular data. Ann Bot 105:661-676. doi:10.1093/aob/ mcq030

Ciraolo G, Cammalleri C, Capodici F et al (2012) Mapping evapotranspiration on vineyards: a comparison between Penman-Monteith and energy balance approaches for operational purposes. In: Neale CMU, Maltese A (eds) SPIE remote sensing. International Society for Optics and Photonics, Bellingham

Codex Standard (2011) Table Grapes No. 255, adoption year 2007, amended year 2011. Publishing Physics Web. http:// www.codexalimentarius.org/standards/list-of-standards/ en/?provide $=$ standards $\&$ orderField $=$ fullReference $\&$ sort $=$ asc\&num1=CODEX. Accessed 30 Aug 2015

Cohen Y, Alchanatis V, Meron M et al (2005) Estimation of leaf water potential by thermal imagery and spatial analysis. J Exp Bot 56:1843-1852. doi:10.1093/jxb/eri174

Cominelli E, Galbiati M, Tonelli C, Bowler C (2009) Water: the invisible problem. EMBO Rep 10:671-676. doi:10.1038/ embor. 2009.148

Comiran F, Bergamaschi H, Heckler BMM et al (2012) Microclimate and production of "Niagara Rosada" grapevines in organic cultivation under plastic covering. Rev Bras Frutic 34:152-159. doi:10.1590/S010029452012000100021

Conceição MAF, Maia JDG, Mandarini Neto J (1998) Informações para a irrigação da videira na região de Jales, SP. Embrapa Uva e Vinho, Comunicado Técnico 30:1-8

Conceição MAF, de Souza RT, Zeoli JDJS, De Paula MVB (2012) Coeficiente de cultura (Kc) para videira com e sem cobertura vegetal no solo. Irrigation 1:234. doi:10.15809/ irriga.2012v1n01p234

Conceição MAF, Savini TC, Souza RT de, dos Santos CP (2014) Irrigation cutoff during ripening stage of Niagara Rosada grapes. In: INOVAGRI international meeting 2, 2014, Fortaleza Anais. Fortaleza INOVAGRI 2896-2901. doi:10.12702/ii.inovagri.2014-a390

Conde A, Regalado A, Rodrigues D et al (2015) Polyols in grape berry: transport and metabolic adjustments as a physiological strategy for water-deficit stress tolerance in grapevine. J Exp Bot 66:889-906. doi:10.1093/jxb/eru446

Conesa MR, de la Rosa JM, Artés-Hernández F et al (2015) Long-term impact of deficit irrigation on the physical quality of berries in "Crimson Seedless" table grapes. J Sci Food Agric 95:2510-2520. doi:10.1002/jsfa.6983

Conesa MR, Falagán N, de la Rosa JM et al (2016) Post-veraison deficit irrigation regimes enhance berry coloration and health-promoting bioactive compounds in "Crimson Seedless" table grapes. Agric Water Manag 163:9-18. doi:10.1016/j.agwat.2015.08.026

Cortell JM, Halbleib M, Gallagher AV, Righetti TL, Kennedy JA (2007) Influence of vine vigor on grape (Vitis vinifera $\mathrm{L}$. cv. Pinot Noir) anthocyanins. 1. Anthocyanin concentration and composition in fruit. J Agric Food Chem 55:6575-6584
Costa JM, Ortuño MF, Chaves MM (2007) Deficit irrigation as a strategy to save water: physiology and potential application to horticulture. J Integr Plant Biol 49:1421-1434. doi:10. 1111/j.1672-9072.2007.00556.x

Costa JM, Lopes CM, Rodrigues ML et al (2012a) Deficit irrigation in Mediterranean vineyards - a tool to increase water use efficiency and to control grapevine and berry growth. Acta Hortic 931:159-170

Costa JM, Ortuño MF, Lopes CM, Chaves MM (2012b) Grapevine varieties exhibiting differences in stomatal response to water deficit. Funct Plant Biol 39:179. doi:10. 1071/FP11156

Costa JM, Grant OM, Chaves MM (2013) Thermography to explore plant-environment interactions. J Exp Bot 64:3937-3949. doi:10.1093/jxb/ert029

Costa JM, Vaz M, Escalona J et al (2016) Modern viticulture in southern Europe: vulnerabilities and strategies for adaptation to water scarcity. Agric Water Manag. doi:10.1016/j. agwat.2015.08.021

Cubero S, Diago MP, Blasco J et al (2015) A new method for assessment of bunch compactness using automated image analysis. Aust J Grape Wine Res 21:101-109. doi:10.1111/ ajgw. 12118

Curtis MA (2013) Influence of cover crop residue management on soil moisture, vine growth, and productivity in a preproduction vineyard in the Willamette Valley. Dissertation, Oregon State University. http://hdl.handle.net/1957/ 40103

Dai ZW, Ollat N, Gomes E et al (2011) Ecophysiological, genetic, and molecular causes of variation in grape berry weight and composition: a review. Am J Enol Vitic 62:413-425. doi:10.5344/ajev.2011.10116

Dai ZW, Léon C, Feil R et al (2013) Metabolic profiling reveals coordinated switches in primary carbohydrate metabolism in grape berry (Vitis vinifera L.), a non-climacteric fleshy fruit. J Exp Bot 64:1345-1355. doi:10.1093/jxb/ers396

Davies WJ, Zhang J (1991) Root Signals and the regulation of growth and development of plants in drying soil. Annu Rev Plant Physiol Plant Mol Biol 42:55-76. doi:10.1146/ annurev.pp.42.060191.000415

Davies WJ, Tardieu F, Trejo CL (1994) How do chemical signals work in plants that grow in drying soil? Plant Physiol 104:309

Davies C, Boss P, Robinson S (1997) Treatment of grape berries, a nonclimacteric fruit with a synthetic auxin, retards ripening and alters the expression of developmentally regulated genes. Plant Physiol 115:1155-1161

Davies WJ, Bacon MA, Thompson DS et al (2000) Regulation of leaf and fruit growth in plants growing in drying soil: exploitation of the plants' chemical signalling system and hydraulic architecture to increase the efficiency of water use in agriculture. J Exp Bot 51:1617-1626. doi:10.1093/ jexbot/51.350.1617

Davies WJ, Kudoyarova G, Hartung W (2005) Long-distance ABA signaling and its relation to other signaling pathways in the detection of soil drying and the mediation of the plant's response to drought. J Plant Growth Regul 24:285-295. doi:10.1007/s00344-005-0103-1

de Castro Teixeira AH, de Azevedo PV, da Silva BB, Soares JM (1999) Consumo hídrico e coeficiente de cultura da videira 
na região de Petrolina, PE. Rev Bras Eng Agríc Ambient 3(3):413-416

de Mello LMR (2015) Vitivinicultura brasileira: Panorama 2014. Bento Gonçalves: Embrapa Uva e Vinho. Comunicado Técnico 175, $6 \mathrm{p}$

de Souza CR, Maroco JP, dos Santos TP et al (2005) Impact of deficit irrigation on water use efficiency and carbon isotope composition (delta13C) of field-grown grapevines under Mediterranean climate. J Exp Bot 56:2163-2172. doi:10. 1093/jxb/eri216

de Souza CR, da Mota RV, Dias FAN et al (2015) Physiological and agronomical responses of Syrah grapevine under protected cultivation. Bragantia 74(3):270-278. doi:10.1590/ 1678-4499.0047

Della-Marta PM, Haylock MR, Luterbacher J, Wanner H (2007) Doubled length of western European summer heat waves since 1880. J Geophys Res 112:D15103. doi:10.1029/ 2007JD008510

Deluc LG, Quilici DR, Decendit A et al (2009) Water deficit alters differentially metabolic pathways affecting important flavor and quality traits in grape berries of Cabernet Sauvignon and Chardonnay. BMC Genom 10:212. doi:10. 1186/1471-2164-10-212

Demir KOK (2014) A review on grape growing in tropical regions. Turk J Agric For (Special Issue) 1:1236-1241

DGADR (2015) Direção geral de Agricultura e Desenvolimento Rural-Uso eficiente da água. Tabelas de dotação de rega. http://www.dgadr.mamaot.pt/rec/acao-7-5-uso-eficienteda-agua

Dodd IC (2005) Root-to-shoot signalling: assessing the roles of "Up" in the up and down world of long-distance signalling in plants. Plant Soil 274:251-270. doi:10.1007/s11104004-0966-0

Dodd IC (2009) Rhizosphere manipulations to maximize “crop per drop" during deficit irrigation. J Exp Bot 60:2454-2459. doi:10.1093/jxb/erp192

Dodd IC, Theobald JC, Bacon MA, Davies WJ (2006) Alternation of wet and dry sides during partial rootzone drying irrigation alters root-to-shoot signalling of abscisic acid. Funct Plant Biol 33:1081. doi:10.1071/FP06203

Domingos S, Scafidi P, Cardoso V et al (2015) Flower abscission in Vitis vinifera L. triggered by gibberellic acid and shade discloses differences in the underlying metabolic pathways. Front Plant Sci 6:1-18. doi:10.3389/fpls.2015. 00457

dos Santos TP, Lopes CM, Rodrigues ML et al (2003) Partial rootzone drying: effects on growth and fruit quality of field-grown grapevines (Vitis vinifera). Funct Plant Biol 30:663. doi:10.1071/FP02180

Dry P, Loveys B (1999) Grapevine shoot growth and stomatal conductance are reduced when part of the root system is dried. Vitis 38:151-156

Dry PR, Loveys BR, Düring H (2000) Partial drying of the rootzone of grape. II. Changes in the pattern of root development. Vitis 39:9-12

Du T, Kang S, Zhang J et al (2008) Water use efficiency and fruit quality of table grape under alternate partial root-zone drip irrigation. Agric Water Manag 95:659-668. doi:10.1016/j. agwat.2008.01.017

Du T, Kang S, Yan B, Zhang J (2013) Alternate furrow irrigation: a practical way to improve grape quality and water use efficiency in Arid Northwest China. J Integr Agric 12:509-519. doi:10.1016/S2095-3119(13)60252-X

Du F, Deng W, Yang M et al (2015) Protecting grapevines from rainfall in rainy conditions reduces disease severity and enhances profitability. Crop Prot 67:261-268. doi:10.1016/ j.cropro.2014.10.024

Ejsmentewicz T, Balic I, Sanhueza D et al (2015) Comparative study of two table grape varieties with contrasting texture during cold storage. Molecules 20:3667-3680. doi:10. 3390/molecules20033667

El-Ansary D, Okamoto G (2008) Improving table grape quality with less irrigation water in Japan: partial root-zone drying versus regulated deficit irrigation. Acta Hortic 265-271:2008. doi:10.17660/ActaHortic.2008.792.30

Elliott J, Deryng D, Müller C et al (2014) Constraints and potentials of future irrigation water availability on agricultural production under climate change. Proc Natl Acad Sci USA 111:3239-3244. doi:10.1073/pnas.1222474110

English M (1990) Deficit irrigation. I: analytical framework. J Irrig Drain Eng 116:399-412. doi:10.1061/(ASCE)07339437(1990)116:3(399)

Escalona JM, Flexas J, Medrano H (1999) Stomatal and nonstomatal limitations of photosynthesis under water stress in field-grown grapevines. Aust J Plant Physiol 26:421. doi:10.1071/PP99019

EU (2015) Agricultural production. http://ec.europa.eu/eurostat/ statistics-explained/index.php/Agricultural_production_-orchards\#Vines_producing_table_grapes. Accessed 30 Aug 2015

Faci JM, Blanco O, Medina ET, Martínez-Cob A (2014) Effect of post veraison regulated deficit irrigation in production and berry quality of Autumn Royal and Crimson table grape cultivars. Agric Water Manag 134:73-83. doi:10.1016/j.agwat.2013.11.009

FAO (2011) The state of the world's land and water resources for food and agriculture (SOLAW) - managing systems at risk. FAO and Earthscan. www.fao.org/docrep/017/ i1688e/i1688e.pdf

Fereres E, Soriano MA (2007) Deficit irrigation for reducing agricultural water use. J Exp Bot 58:147-159. doi:10.1093/ jxb/erl165

Fernandes de Oliveira A, Nieddu G (2013) Deficit irrigation strategies in Vitis vinifera L. cv. Cannonau under Mediterranean climate. Part II-cluster microclimate and anthocyanin accumulation patterns. S Afr J Enol Vitic 34:184-195

Ferrandino A, Lovisolo C (2014) Abiotic stress effects on grapevine (Vitis vinifera $L$.): focus on abscisic acid-mediated consequences on secondary metabolism and berry quality. Environ Exp Bot 103:138-147. doi:10.1016/j. envexpbot.2013.10.012

Ferrara G, Mazzeo A, Matarrese AMS et al (2015) Application of abscisic acid (S-ABA) and sucrose to improve colour, anthocyanin content and antioxidant activity of cv. Crimson Seedless grape berries. Aust J Grape Wine Res 21:18-29. doi:10.1111/ajgw.12112

Ferreira EA, Regina MdA, Chalfun NNJ, Antunes LEC (2004) Harvest anticipation for "Niagara Rosada" grapes in southern Minas Gerais, Brazil. Ciência e Agrotecnologia 28:1221-1227. doi:10.1590/S1413-70542004000600001

Ferreyra R, Selles G, Silva H et al (2006) Efecto del agua aplicada en las relaciones hídricas y productividad de la vid 
"Crimson Seedless". Pesqui Agropecuária Bras 41:1109-1118. doi:10.1590/S0100-204X2006000700006

Fiorani F, Rascher U, Jahnke S, Schurr U (2012) Imaging plants dynamics in heterogenic environments. Curr Opin Biotechnol 23:227-235. doi:10.1016/j.copbio.2011.12.010

Flexas J, Barón M, Bota J et al (2009) Photosynthesis limitations during water stress acclimation and recovery in the drought-adapted Vitis hybrid Richter-110 (V. berlandieri $\times V$. rupestris). J Exp Bot 60(8):2361-2377. doi:10.1093/jxb/erp069

Flexas J, Galmes J, Galle A et al (2010) Improving water use efficiency in grapevines: potential physiological targets for biotechnological improvement. Aust J Grape Wine Res 16:106-121

Fraga H, Santos JA, Malheiro AC et al (2015) Climatic suitability of Portuguese grapevine varieties and climate change adaptation. Int J Climatol. doi:10.1002/joc.4325

FRUITLINKCO (2015) http://www.fruitlinkco.com/home/ starting-of-new-harvest-for-seedless-grapes/\#respond

Gago J, Douthe C, Coopman RE et al (2015) UAVs challenge to assess water stress for sustainable agriculture. Agric Water Manag 153:9-19. doi:10.1016/j.agwat.2015.01.020

Galbignani M, Merli MC, Magnanini E et al (2016) Gas exchange and water-use efficiency of cv. Sangiovese grafted to rootstocks of varying water-deficit tolerance. Irrig Sci 34:105-116

Gálvez R, Callejas R, Reginato G, Peppi MC (2014) Irrigation schedule on table grapes by stem water potential and vapor pressure deficit allows to optimize water use. Cienc Tec Vitivinic 29:60-70. doi:10.1051/ctv/20142902060

Gambetta GA, Manuck CM, Drucker ST et al (2012) The relationship between root hydraulics and scion vigour across Vitis rootstocks: what role do root aquaporins play? J Exp Bot 63:6445-6455

García-Tejero IF, Durán-Zuazo VH, Muriel-Fernández JL (2014) Towards sustainable irrigated Mediterranean agriculture: implications for water conservation in semi-arid environments. Water Int 39:635-648. doi:10.1080/ 02508060.2014 .931753

Geerts S, Raes D (2009) Deficit irrigation as an on-farm strategy to maximize crop water productivity in dry areas. Agric Water Manag 96:1275-1284. doi:10.1016/j.agwat.2009. 04.009

Gerardi MH, Zimmerman MC (2005) Wastewater pathogens. Wiley, Hoboken. doi:10.1002/0471710431.ch1

Gerling C (2015) Environmentally sustainable viticulture: practices and practicality. Apple Academic Press, Canada

Granett J, Walker MA, Kocsis L, Omer AD (2001) Biology and management of grape phylloxera. Annu Rev Entomol 46:387-412. doi:10.1146/annurev.ento.46.1.387

Grant OM, Ochagavía H, Baluja J et al (2016) Thermal imaging to detect spatial and temporal variation in the water status of grapevine (Vitis vinifera L.). J Hortic Sci Biotech 91(1):44-55

Greer DH (2012) Modelling leaf photosynthetic and transpiration temperature-dependent responses in Vitis vinifera cv. Semillon grapevines growing in hot, irrigated vineyard conditions. AoB Plants 2012:13. doi:10.1093/aobpla/pls009

Greer DH, Weedon MM (2013) The impact of high temperatures on Vitis vinifera cv. Semillon grapevine performance and berry ripening. Front Plant Sci 4:491. doi:10.3389/fpls. 2013.00491

Hayman P, Longbottom M, McCarthy M, Thomas D (2012) Managing grapevines during heatwaves. GWRDC, Australia

Hochberg U, Degu A, Fait A, Rachmilevitch S (2013) Near isohydric grapevine cultivar displays higher photosynthetic efficiency and photorespiration rates under drought stress as compared with near anisohydric grapevine cultivar. Physiol Plant 147:443-452. doi:10.1111/j.1399-3054. 2012.01671.x

INTRACEN (2015) World table grape market in adjustment phase. Publishing Physics Web. http://www.intracen.org/itc/ blogs/market-insider/world-table-grape-market-in-adjust ment-phase/. Accessed 10 Dec 2015

Intrigliolo DS, Pérez D, Risco D et al (2012) Yield components and grape composition responses to seasonal water deficits in Tempranillo grapevines. Irrig Sci 30:339-349. doi:10. 1007/s00271-012-0354-0

INE (2014) Instituto Nacional de Estatística-Estatísticas Agrícolas 2014, Portugal. https://www.ine.pt/ngt_server/ attachfileu.jsp?look_parentBoui=232643723\&att_display= n\&att_download=y

INNOVINE (2015) Innovine, combining innovation in vineyard management and genetic diversity for a sustainable European viticulture. http://www.innovine.eu/home.html. Accessed 10 Dec 2015

INV (2014) Instituto Nacional de Vitivinicultura, Argentina. http://www.inv.gov.ar/inv_contenidos/pdf/estadisticas/ anuarios/2014/Registro14.pdf

IPCC (2013) Climate Change 2013: the physical science basis. I Contribution of Working Group I to the Fifth Assessment Report of the Intergovernmental Panel on Climate Change, First. Cambridge University Press, Cambridge

Jogaiah S, Oulkar DP, Vijapure AN et al (2013) Influence of canopy management practices on fruit composition of wine grape cultivars grown in semi-arid tropical region of India. Afr J Agric Res 8(26):3462-3472. doi:10.5897/AJAR12. 7307

Jones HG (2004) Irrigation scheduling: advantages and pitfalls of plant-based methods. J Exp Bot 55:2427-2436. doi:10. 1093/jxb/erh213

Jones HG, Grant O (2016) Remote sensing and other imaging technologies to monitor grapevine performance. In: Gerós $\mathrm{H}$, Chaves MM, Medrano H, Delrot S (eds) Grapevine under environmental stress: from ecophysiology to molecular mechanisms. Wiley-Blackwell, Hoboken, pp 179-201

Jones HG, Vaughan R (2010) Remote sensing of vegetation: principles, techniques, and applications. Oxford University Press, Oxford

Jones GV, Reid R, Aleksander Vilks (2012) Climate, grapes, and wine: Structure and suitability in a variable and changing climate. In: The geography of wine-regions, terroir and techniques, pp 109-133. doi:10.1007/978-94007-0464-0

Kamiloğlu Ö, Polat A, Durgaç C (2011) Comparison of open field and protected cultivation of five early table grape cultivars under Mediterranean conditions. Turk J Agric For 35:491-499. doi:10.3906/tar-1002-718 
Kang S, Zhang J (2004) Controlled alternate partial root-zone irrigation: its physiological consequences and impact on water use efficiency. J Exp Bot 55:2437-2446. doi:10. 1093/jxb/erh249

Kicherer A, Roscher R, Herzog K et al (2013) BAT (Berry Analysis Tool): a high-throughput image interpretation tool to acquire the number, diameter, and volume of grapevine berries. Vitis 52(3):129-135

Knipfer T, Eustis A, Brodersen C et al (2015) Grapevine species from varied native habitats exhibit differences in embolism formation/repair associated with leaf gas exchange and root pressure. Plant, Cell Environ 38:1503-1513. doi:10. 1111/pce.12497

Kopyt M, Ton Y (2005) Phytomonitoring technique for table grapes. PhyTech, Rehovot

Koundouras S, Hatzidimitriou E, Karamolegkou M et al (2009) Irrigation and rootstock effects on the phenolic concentration and aroma potential of Vitis vinifera L. cv. cabernet sauvignon grapes. J Agric Food Chem 57:7805-7813. doi:10.1021/jf901063a

Kuhn N, Guan L, Dai ZW et al (2014) Berry ripening: recently heard through the grapevine. J Exp Bot 65:4543-4559. doi:10.1093/jxb/ert395

Lanyon D, Hansen D, Cass A (2004) The effect of soil properties on vine performance. CSIRO Land and Water Technical Report, Australia

Laurenson S, Bolan NS, Smith E, McCarthy M (2012) Review: use of recycled wastewater for irrigating grapevines. Aust $\mathrm{J}$ Grape Wine Res 18:1-10. doi:10.1111/j.1755-0238.2011. 00170.x

Levidow L, Zaccaria D, Maia R et al (2014) Improving waterefficient irrigation: prospects and difficulties of innovative practices. Agric Water Manag 146:84-94. doi:10.1016/j. agwat.2014.07.012

Liu G-T, Wang J-F, Cramer G et al (2012) Transcriptomic analysis of grape (Vitis vinifera $\mathrm{L}$.) leaves during and after recovery from heat stress. BMC Plant Biol 12:10. doi:10. 1186/1471-2229-12-174

Lopes CM, Costa JM, Monteiro A et al (2014) Varietal behavior under water and heat stress. In: Proceedings of the congress of OENOVITI international network, Germany, pp 50-56

Loveys B, Stoll M, Davies W (2004) Physiological approaches to enhance water use efficiency in agriculture: exploiting plant signalling in novel irrigation practice. In: Bacon MA (ed) Water use efficiency in plant biology. University of Lancaster, Lancaster, pp 113-141

Lovisolo C, Schubert A (2000) Downward shoot positioning affects water transport in field-grown grapevines. Vitis 39(2):49-53

Lovisolo C, Tramontini S, Flexas J, Schubert A (2008) Mercurial inhibition of root hydraulic conductance in Vitis spp. rootstocks under water stress. Environ Exp Bot 63(1):178-182

MAGRAMA (2015) Boletín Mensual de Estadística, Julio 2015, España. 60 p. http://www.magrama.gob.es/es/estadistica/ temas/publicaciones/bme-2015-7-julio_tcm7-390999.pdf

Mancosu N, Snyder R, Kyriakakis G, Spano D (2015) Water scarcity and future challenges for food production. Water 7:975-992. doi:10.3390/w7030975

Marinho LB, Rodrigues JJV, Soares JM et al (2009) Production and quality of "Superior Seedless" grapes under irrigation restrictions during berry maturation. Pesqui Agropecuária Bras 44:1682-1691. doi:10.1590/S0100-204X2009001 200018

Marsal J, Mata M, Arbonés A et al (2002) Regulated deficit irrigation and rectification of irrigation scheduling in young pear trees: an evaluation based on vegetative and productive response. Eur J Agron 17:111-122. doi:10. 1016/S1161-0301(02)00002-3

Martínez Barba MC (2015) Estudio comparativo de las relaciones hídricas y producción en uva de mesa bajo riego deficitario (RD) y desecación parcial de raíces (DPR) Efecto del déficit continuo y controlado. Dissertation, Universidad Politécnica de Cartagena. http://hdl.handle. net/10317/5022

Matese A, Di Gennaro SF (2015) Technology in precision viticulture: a state of the art review. Int J Wine Res 7:69. doi:10.2147/IJWR.S69405

McCarthy MG, Loveys BR, Dry PR, Stoll M (2002) Regulated deficit irrigation and partial rootzone drying as irrigation management techniques for grapevines. In: Deficit irrigation practices, 22nd edn. FAO Water Reports, Rome, pp 79-87

Medrano H, Flexas J, Ribas-Carbó M, Gulías J (2010) Measuring water use efficiency in grapevines. In: Methodologies and results in grapevine research. Springer, Dordrecht, pp 123-134

Medrano H, Tomás M, Martorell S et al (2015) Improving water use efficiency of vineyards in semi-arid regions-a review. Agron Sustain Dev 35:499-517. doi:10.1007/s13593-0140280-Z

Molden D, Oweis T, Steduto P et al (2010) Improving agricultural water productivity: between optimism and caution. Agric Water Manag 97:528-535. doi:10.1016/j.agwat. 2009.03.023

Moratiel R, Martínez-Cob A (2012) Evapotranspiration of grapevine trained to a gable trellis system under netting and black plastic mulching. Irrig Sci 30:167-178. doi:10.1007/ s00271-011-0275-3

Morison JI, Baker N, Mullineaux P, Davies W (2008) Improving water use in crop production. Philos Trans R Soc B Biol Sci 363:639-658. doi:10.1098/rstb.2007.2175

Myburgh P (2003) Responses of Vitis vinifera L. cv. Sultanina to water deficits during various pre-and post-harvest phases under semi-arid conditions. S Afr J Enol Vitic 24:25-33

Netzer Y (2010) A model for irrigation of vineyards under limited water availability. Thesis, Hebrew University of Jerusalem

Netzer Y, Yao C, Shenker M, Bravdo B (2005) Water consumption of "Superior" grapevines grown in a semiarid region. Acta Hortic 689:399-406. doi:10.17660/ ActaHortic.2005.689.47

Netzer Y, Yao C, Shenker M et al (2009) Water use and the development of seasonal crop coefficients for Superior Seedless grapevines trained to an open-gable trellis system. Irrig Sci 27:109-120. doi:10.1007/s00271-008-0124-1

Netzer Y, Shenker M, Schwartz A (2014) Effects of irrigation using treated wastewater on table grape vineyards: dynamics of sodium accumulation in soil and plant. Irrig Sci 32:283-294. doi:10.1007/s00271-014-0430-8

Niculcea M, López J, Sánchez-Díaz M, Carmen Antolín M (2014) Involvement of berry hormonal content in the 
response to pre- and post-veraison water deficit in different grapevine (Vitis vinifera L.) cultivars. Aust J Grape Wine Res 20:281-291. doi:10.1111/ajgw.12064

Nóbrega HPV (2013) Utilização de redes de ensombramento para monda de bagos em uva de mesa. Dissertation, Instituto Superior de Agronomia

Novello V, de Palma L (2008) Growing grapes under cover. Acta Hortic 785:353-362. doi:10.17660/ActaHortic.2008. 785.44

Ollat N, Peccoux A, Papura D et al (2016) In: Gerós H, Chaves M, Medrano H, Delrot S (eds) Grapevine in a changing environment: a molecular and ecophysiological perspective. Wiley-Blackwell, Hoboken, pp 68-108

Peacock W, Jensen F, Dokoozlian N (1994) Training-trellis systems and canopy management of table grapes in California. University of California. http://cetulare.ucdavis. edu/files/82023.pdf. Accessed 9 Nov 2015

Peppi MC, Fidelibus MW, Dokoozlian N (2006) Abscisic acid application timing and concentration affect firmness, pigmentation, and color of 'flame seedless' grapes. HortScience 41(6): 1440-1445

Peppi MC, Walker MA, Fidelibus MW (2008) Application of abscisic acid rapidly upregulated UFGT gene expression and improved color of grape berries. Vitis 47(1):11-14

Pereira LS, Cordery I, Iacovides I (2012) Improved indicators of water use performance and productivity for sustainable water conservation and saving. Agric Water Manag 108:39-51. doi:10.1016/j.agwat.2011.08.022

Proffitt T, Clause JC (2011) Irrigation management for table grapes in a drying environment. http://www.per thregionnrm.com/media/10646/tablegrape_management_ casestudy_30.01.11_web.pdf

Rana G, Katerji N, Introna M, Hammami A (2004) Microclimate and plant water relationship of the "overhead" table grape vineyard managed with three different covering techniques. Sci Hortic (Amsterdam) 102:105-120. doi:10. 1016/j.scienta.2003.12.008

Reynolds AG, Vanden-Heuvel JE (2009) Influence of grapevine training systems on vine growth and fruit composition: a review. Am J Enol Vitic 60(3):251-268

Ritschel PS, Girardi CL, Zanus MC et al (2015) Novel Brazilian grape cultivars. Acta Hortic 1082:157-163. doi:10.17660/ ActaHortic.2015.1082.21

Roberto SR, Colombo LA, de Assis AM (2011) Review: protect cultivation in viticulture. Cienc Tec Vitivinic 26:11-16

Roby G, Matthews MA (2004) Relative proportions of seed, skin and flesh, in ripe berries from Cabernet Sauvignon grapevines grown in a vineyard either well irrigated or under water deficit. Aust J Grape Wine Res 10:74-82. doi:10.1111/j.1755-0238.2004.tb00009.x

Rodríguez JC, Grageda J, Watts CJ et al (2010) Water use by perennial crops in the lower Sonora watershed. J Arid Environ 74:603-610. doi:10.1016/j.jaridenv.2009.11.008

Rustioni L, Rocchi L, Guffanti E et al (2014) Characterization of grape (Vitis vinifera L.) Berry sunburn symptoms by reflectance. J Agric Food Chem 62:3043-3046. doi:10. 1021/jf405772f

Santesteban LG, Miranda C, Royo JB (2009) Effect of water deficit and rewatering on leaf gas exchange and transpiration decline of excised leaves of four grapevine (Vitis vinifera L.) cultivars. Sci Hortic 121(4):434-439
Santos TP, Lopes CMA, Rodrigues ML et al (2005) Effects of partial root-zone drying irrigation on cluster microclimate and fruit composition of field-grown Castelão grapevines. Vitis 44:117-125

Satisha J, Prakash G (2006) The influence of water and gas exchange parameters on grafted grapevines under conditions of moisture stress. S Afr J Enol Vitic 27(1):40-45

Satisha J, Prakash G, Venugopalan R (2006) Statistical modeling of the effect of physio-biochemical parameters on water use efficiency of grape varieties, rootstocks and their stionic combinations. Turk J Agric For 30:261-271

Satisha J, Ramteke SD, Karibasappa GS (2007) Physiological and biochemical characterisation of grape rootstocks. S Afr J Enol Vitic 28(2):163-168

Scheierling SM, Bartone CR, Mara DD, Drechsel P (2011) Towards an agenda for improving wastewater use in agriculture. Water Int 36:420-440. doi:10.1080/02508060. 2011.594527

Seccia A, Santeramo FG, Nardone G (2015) Trade competitiveness in table grapes: a global view. Outlook Agric 44:127-134. doi:10.5367/oa.2015.0205

Serman FV, Liotta M, Parera C (2004) Effects of irrigation deficit on table grape cv. Superior Seedless production. Acta Hortic 646:183-186. doi:10.17660/ActaHortic.2004.646.23

Serra I, Strever A, Myburgh PA, Deloire A (2014) Review: the interaction between rootstocks and cultivars (Vitis vinifera L.) to enhance drought tolerance in grapevine. Aust J Grape Wine Res 20:1-14. doi:10.1111/ajgw.12054

Shellie K (2011) Interactive effects of deficit irrigation and berry exposure aspect on Merlot and Cabernet Sauvignon in an arid climate. Am J Enol Vitic 62:462-470. doi:10.5344/ ajev.2011.10103

Shinomiya R, Fujishima H, Muramoto K, Shiraishi M (2015) Impact of temperature and sunlight on the skin coloration of the "Kyoho" table grape. Sci Hortic (Amsterdam) 193:77-83. doi:10.1016/j.scienta.2015.06.042

Sica C, Loisi R V., Blanco I et al (2015) SWOT analysis and land management of plastic wastes in agriculture. In: Proceedings of the 43rd international symposium on agricultural engineering, actual tasks on agricultural engineering, Opatija, 24-27 February 2015. University of Zagreb, pp 745-754

Silva-Contreras C, Sellés-Von Schouwen G, Ferreyra-Espada R, Silva-Robledo H (2012) Variation of water potential and trunk diameter answer as sensitivity to the water availability in table grapes. Chil J Agric Res 72:459-469. doi:10.4067/S0718-58392012000400001

Soar CJ, Dry PR, Loveys BR (2006) Scion photosynthesis and leaf gas exchange in Vitis vinifera L. cv. Shiraz: mediation of rootstock effects via xylem sap ABA. Aust J Grape Wine Res 12:82-96. doi:10.1111/j.1755-0238.2006.tb00047.x

Soto-García M, Martínez-Alvarez V, García-Bastida P et al (2013) Effect of water scarcity and modernisation on the performance of irrigation districts in south-eastern Spain. Agric Water Manag 124:11-19

Stanghellini C (2014) Horticultural production in greenhouses: efficient use of water. Acta Hortic 1034:25-32. doi:10. 17660/ActaHortic.2014.1034.1

Stoll M, Loveys B, Dry P (2000) Hormonal changes induced by partial rootzone drying of irrigated grapevine. J Exp Bot 51:1627-1634. doi:10.1093/jexbot/51.350.1627 
Strik BC (2011) Growing table grapes. Oregon State University, Extension Service, pp 1-32. http://smallfarms.oregonstate. edu/sites/default/files/publications/growing_table_grapes_ ec1639_may_2011.pdf

Suvočarev K, Blanco O, Faci JM et al (2013) Transpiration of table grape (Vitis vinifera L.) trained on an overhead trellis system under netting. Irrig Sci 31:1289-1302. doi:10.1007/ s00271-013-0404-2

Swinburn G (2014) Making decisions in table grape production with benchmarking data. In: Proceedings of the 7th international table grape symposium, pp 162-164. http:// www.7itgs2014.org/wp-content/uploads/2014/12/ATGASymposium-FINAL-WEB-Version.pdf

Tarricone L, Gentilesco G, Ciccarese A et al (2012) Irrigation strategy affects quantitative and qualitative vine performance of 'Italia' table grape. Acta Hortic 931:203-209. doi:10.17660/ActaHortic.2012.931.22

Tarricone L, Gentilesco G, Di Gennaro D, Amendolagine AM (2014) Irrigation strategy and vine performance of organic "Italia" table grape grown in Apulia region (Southern Italy). In: Proceedings of the 7th international table grape symposium, Australia, pp 97-100

Teixeira ADC, Bastiaanssen WGM, Bassoi LH (2007) Crop water parameters of irrigated wine and table grapes to support water productivity analysis in the Sao Francisco river basin, Brazil. Agric Water Manag 94(1): $31-42$

Teixeira AH, Bastiaanssen W, Ahmad MD, Bos MG (2009) Reviewing SEBAL input parameters for assessing evapotranspiration and water productivity for the Low-Middle São Francisco River basin, Brazil. Part B: application to the regional scale. Agric For Meteorol 149:477-490. doi:10. 1016/j.agrformet.2008.09.014

Teixeira AHdC, Lopes HL, Hernandez FBT (2014) Up scaling table grape water requirements in the Low-Middle São Francisco river basin, Brazil. Acta Hortic 1038:655-662

Tomás M, Medrano H, Pou A et al (2012) Water-use efficiency in grapevine cultivars grown under controlled conditions: effects of water stress at the leaf and whole-plant level. Aust J Grape Wine Res 18:164-172

Tomás M, Medrano H, Escalona JM et al (2014) Variability of water use efficiency in grapevines. Environ Exp Bot 103:148-157. doi:10.1016/j.envexpbot.2013.09.003

Tramontini AS, Vitali M, Centioni L, Schubert A, Lovisolo C (2013) Rootstock control of scion response to water stress in grapevine. Environ Exp Bot 93:20-26

USDA-FAS (2014a) EU-28 Fresh Deciduous Fruit Annual, Ample Domestic Supply and Russian Import Ban to Put Pressure on the Fresh Fruit Market. http://gain.fas.usda.gov/ Recent\%20GAIN\%20Publications/Fresh\%20Deciduous\%20 Fruit\%20Annual_Vienna_EU-28_10-28-2014.pdf

USDA-FAS (2014b) Report. Fresh Deciduous Fruit Annual. http:/gain.fas.usda.gov/Recent\%20GAIN\%20Publications/ Fresh\%20Deciduous\%20Fruit\%20Annual\%202014_Rome_ Italy_10-28-2014.pdf

USDA-FAS (2014c) Report. Fresh Deciduous Fruit Annual. http:/gain.fas.usda.gov/Recent\%20GAIN\%20Publications/ Fresh\%20Deciduous\%20Fruit\%20Annual_Beijing_China\% 20-\%20Peoples\%20Republic\%20of_12-29-2014.pdf
USDA-FAS (2014d) Report. Fresh Deciduous Fruit Annual. http://gain.fas.usda.gov/Recent\%20GAIN\%20Publications/ Fresh\%20Deciduous\%20Fruit\%20Annual_Ankara_Turkey_ 11-13-2014.pdf

USDA-FAS (2014e) Report. Fresh Deciduous Fruit Annual. http:/gain.fas.usda.gov/Recent\%20GAIN\%20Publications/ Fresh\%20Deciduous\%20Fruit\%20Annual_Lima_Peru_109-2014.pdf

USDA-FAS (2015a) Fresh Deciduous Fruit: world markets and trade (apples, grapes, \& pears). http://apps.fas.usda.gov/ psdonline/circulars/fruit.pdf. Dec 2015

USDA-FAS (2015b) Noncitrus fruits and nuts 2014 summary. http://usda.mannlib.cornell.edu/usda/current/NoncFruiNu/ NoncFruiNu-07-17-2015.pdf

USDA-FAS (2015c) Report. Fresh Deciduous Fruit Annual. http://gain.fas.usda.gov/Recent\%20GAIN\%20Publications/ Fresh\%20Deciduous\%20Fruit\%20Semi-annual_Santiago_ Chile_5-12-2015.pdf

USDA-FAS (2015d) Report. Fresh Deciduous Fruit Annual. http:/gain.fas.usda.gov/Recent\%20GAIN\%20Publications/ Fresh\%20Deciduous\%20Fruit\%20Semi-annual_Pretoria_ South\%20Africa\%20-\%20Republic\%20of_5-15-2015. pdf

Vanino S, Pulighe G, Nino P et al (2015) Estimation of evapotranspiration and crop coefficients of tendone vineyards using multi-sensor remote sensing data in a mediterranean environment. Remote Sens 7:14708-14730. doi:10.3390/ rs71114708

Van Zyl T (2007) The effect of partial rootzone drying and foliar nutrition on water use efficiency and quality of table grape cultivars Crimson seedless and Dauphine. Dissertation, Stellenbosch University

Vicente-Serrano SM, Lopez-Moreno JI, Beguería S et al (2014) Evidence of increasing drought severity caused by temperature rise in southern Europe. Environ Res Lett 9:044001. doi:10.1088/1748-9326/9/4/044001

Villagra P, de García CV, Ferreyra R et al (2014) Estimation of water requirements and Kc values of 'Thompson Seedless' table grapes grown in the overhead trellis system, using the eddy covariance method. Chil J Agric Res 74:213-218. doi:10.4067/S0718-58392014000200013

Vogel S (2009) Leaves in the lowest and highest winds: temperature, force and shape. New Phytol 183:13-26. doi:10. 1111/j.1469-8137.2009.02854.x

Vox G, Schettini E, Scarascia-Mugnozza G et al (2014) Crimson seedless table grape grown under plastic film: ecophysiological parameters and grape characteristics as affected by the irrigation volume. In: Proceedings of the international conference of agricultural engineering, Zurich, $8 \mathrm{p}$

Weber E, Grattan S, Hanson B et al (2014) Recycled water causes no salinity or toxicity issues in Napa vineyards. Calif Agric 68:59-67

Whitfield D, Abuzar M, McAllister A et al (2014) Satellite-based assessments of irrigation water use by table grapes grown in the Robinvale district of SE Australia. In: 7th international table grape symposium, Australia, pp 106-108

Williams L (2012) Potential vineyard evapotranspiration (ET) due to global warming: comparison of vineyard ET at three locations in California differing in mean seasonal 
temperatures. Acta Hortic 931:221-226. doi:10.17660/ ActaHortic.2012.931.24

Williams LE, Ayars JE (2005) Grapevine water use and the crop coefficient are linear functions of the shaded area measured beneath the canopy. Agric For Meteorol 13:201-211

Williams LE, Grimes DW, Phene CJ (2010) The effects of applied water at various fractions of measured evapotranspiration on reproductive growth and water productivity of Thompson Seedless grapevines. Irrig Sci 28:233-243. doi:10.1007/s00271-009-0173-0

Wine Institute (2014) World vineyard acreage by country 2014. http://www.wineinstitute.org/files/World_Vineyard_Acre age_by_Country_2014_cTradeDataAndAnalysis.pdf

Zarrouk O, Costa JM, Francisco R et al (2016) Drought and water management in Mediterranean vineyards. In: Gerós $\mathrm{H}$, Chaves M, Medrano H, Delrot S (eds) Grapevine in a changing environment: a molecular and ecophysiological perspective. Wiley-Blackwell, Hoboken, pp 38-67

Zhang J, Schurr U, Davies WJ (1987) Control of stomatal behaviour by abscisic acid which apparently originates in the roots. J Exp Bot 38:1174-1181. doi:10.1093/jxb/38.7. 1174

Zhang X, Walker RR, Stevens RM, Prior LD (2002) Yieldsalinity relationships of different grapevine (Vitis vinifera L.) scion-rootstock combinations. Aust J Grape Wine Res 8:150-156. doi:10.1111/j.1755-0238.2002.tb00250.x

Zhang Q, Wang S, Inoue M (2012) A new methodology for determining irrigation schedule of grapevines using photogrammetric measurement of berry diameter. J Food Agric Environ 10:582-587

Zimmermann U (2013) The future of water relations of plants. Theor Exp Plant Physiol 25:241-243. doi:10.1590/S219700252013005000005

Zúñiga-Espinoza C, Aspillaga C, Ferreyra R, Selles G (2015) Response of table grape to irrigation water in the Aconcagua Valley, Chile. Agronomy 5:405-417. doi:10.3390/ agronomy5030405 